\title{
Late Summer Distribution of Cetaceans near Barrow, Alaska: Results from Aerial Surveys Conducted During the Bowhead Whale Feeding Ecology Study, 2007-11
}

\author{
KIM E. W. SHELDEN, JULIE A. MOCKLIN, KIMBERLY T. GOETZ, DAVID J. RUGH, \\ LINDA VATE BRATTSTRÖM, and NANCY A. FRIDAY
}

\section{Introduction}

Bowhead whales, Balaena mysticetus, are distributed in seasonally ice covered waters of the Arctic and sub-

Kim Shelden (kim.shelden@noaa.gov), Julie Mocklin, Kim Goetz, Linda Vate Brattström, and Nancy Friday are with the Marine Mammal Laboratory (MML), Alaska Fisheries Science Center, National Marine Fisheries Service, NOAA, 7600 Sand Point Way N.E., Seattle, WA 98115-6349. Julie Mocklin and Linda Vate Brattström are currently with the Joint Institute for the Study of the Atmosphere and Ocean (JISAO), 3737 Brooklyn Ave NE, Seattle, WA 98105. Kim Goetz is currently with the National arctic. For management purposes, four bowhead whale stocks are currently recognized by the International Whaling Commission (IWC) (IWC, 2010) and are protected under the U.S. Marine Mammal Protection Act and U.S.

Institute of Water and Atmospheric Research, Ltd., 301 Evans Bay Parade, Greta Point, Wellington 6021 NZ. Dave Rugh (retired MML) is at 17416 95th Ave. NE, Bothell, WA 98011. The findings and conclusions in this paper are those of the author(s) and do not necessarily represent the views of the National Marine Fisheries Service, NOAA.

doi: https://doi.org/10.7755/MFR.79.2.1
Endangered Species Act (Muto et al., 2016). These stocks occur in the Okhotsk Sea (Russian waters), Davis Strait and Hudson Bay (western Greenland and eastern Canadian waters), the eastern North Atlantic (the Spitsbergen stock near Svalbard), and the Bering/Chukchi/Beaufort seas.

The latter is the Western Arctic stock, the largest remnant population and only stock found within U.S. waters (Rugh et al., 2003), generally north of lat. $54^{\circ} \mathrm{N}$ and south of lat. $75^{\circ} \mathrm{N}$ in the western Arctic Basin (Moore and Reeves, 1993). This
ABSTRACT-The aerial survey component of the Bowhead Whale Feeding Ecology Study (BOWFEST) was designed to document patterns and variability in the timing and distribution of bowhead whales, Balaena mysticetus, and to provide an estimate of temporal and spatial habitat use near Barrow, Alaska. Aerial surveys were conducted from late August to mid-September during the period 2007-11 for a total of 171.1 hours flown. In addition to the focal species, observed species included gray whales, Eschrichtius robustus; one humpback whale, Megaptera novaeangliae; beluga whales, Delphinapterus leucas; ringed seals, Phoca hispida; bearded seals, Erignathus barbatus; walrus, Odobenus rosmarus; and polar bears, Ursus maritimus. Small pinnipeds, such as ringed seal and spotted seals, Phoca largha, were often difficult to differentiate and identify to species given the relatively high survey altitude of $310 \mathrm{~m}$ $(1,000 \mathrm{ft})$.

Habitat partitioning was evident among the cetacean species observed in greatest numbers: bowhead, gray, and beluga whales. Abundance estimates during this time period ranged from 22 (CV 0.80) to 213 (CV 0.30) bowhead whales, 1 (CV 1.01) to 18 ( $C V$ 0.28) gray whales, and 0 to 948 (CV 0.66) beluga whales. Standard deviation ellipses showed each species occupied a unique region within the study area with slight overlaps occurring in some years. Bowhead distribution was oriented along the barrier islands and $20 \mathrm{~m}$ isobath on the continental shelf and also included parts of the Barrow Canyon and shelf break that were close to shore. Gray whale distribution oriented along the Barrow Canyon shelf break near the $50 \mathrm{~m}$ isobath; while beluga distribution ellipses centered over Barrow Canyon and offshore slope waters. A four-parameter presence-absence model (bathymetry, bathymetric slope, distance from shore, and distance from the shelf break) found both distance from shore and shelf break were significant in predicting the presence of bowhead whales. All four parameters were significant in predicting gray whale presence. Only bathymetry was significant in predicting beluga whale presence.

During the 5-year study, 664 unique bowhead whales were identified from 1,415 photographic images. Observers noted feeding behavior during 7-50\% of sightings and $15-49 \%$ of photographed whales exhibited feeding behavior in any given year. Of the individual whales that were visually or photographically identified as feeding, 81-90\% were in shelf waters, and the majority of those were clustered around the $20 \mathrm{~m}$ isobath. More feeding behavior was observed and photographed during years when most sightings occurred on the shelf (2007, 2009, and 2010) but not necessarily in years when bowheads were most abundant in the study area (e.g., 2008 and 2010). The lowest percent feeding both visually and photographically occurred in 2008, the only year whale swim direction was predominately westerly, and open mouth (skim) feeding behavior was not observed.

Although the paucity of individual resightings (based on photographic recaptures) between survey days (3 matches out of 664 identified whales) suggested very low residence times, the photogrammetric sample (654 whales) was largely comprised of juveniles (65\%). Young whales typically are unmarked and, therefore, not matched (only 3-6\% were highly or moderately marked in at least one zone on the body). All intrayear matched whales moved east of their original sighting location, which was not expected so close to the westbound fall migration.

The BOWFEST aerial study provides a 5-year record of late summer presence of cetaceans in the western Beaufort Sea, adding to the growing body of knowledge on these species and their habitat preferences in this region. This information is particularly important since the western Beaufort Sea is undergoing rapid change as the bowhead whale population continues to grow, other species extend their ranges and increase their numbers in the area, and industrial activity, commercial fishing, and shipping operations are expected to increase in the Arctic as sea ice decreases. 
stock migrates annually from the Bering Sea through the Chukchi to the Beaufort Sea in the spring. During the spring migration, bowhead whales typically begin arriving in the Barrow (now Utqiagivik), Alaska, area in early April and continue migrating through until late June (Moore and Reeves, 1993). The fall migration generally begins in early September and continues to mid-October as bowhead whales migrate west across inner shelf waters (Moore et al., 2000) out of the Beaufort and into the Chukchi Sea, as evidenced during previous aerial surveys (Moore et al., 1989; Moore and Clarke, 1992; Richardson ${ }^{1}$; Ljungblad et $\mathrm{al}^{2}{ }^{2}$ ) and satellite-tracking (Quakenbush et al., 2010; Citta et al., 2015).

These whales are important to Native subsistence hunters of Alaska, Russia, and Canada, and hunting is regulated through IWC quotas shared between Alaska and the Russian Federation. ${ }^{3}$ Barrow is the largest of the Native subsistence whaling villages, landing roughly half of the total number of bowhead whales hunted each year (Suydam and George ${ }^{4}$ ).

Bowhead whale feeding activity has been well documented in the eastern Beaufort Sea (e.g., Richardson ${ }^{1}$ ) but only occasionally observed in other areas along the migratory route, particularly during the fall (Ljungblad et

${ }^{1}$ Richardson, W. J. (Editor). 1987. Importance of the eastern Alaskan Beaufort Sea to feeding bowhead whales, 1985-86. Rep. to U.S. Minerals Manag. Serv. by LGL Inc., NTIS No. PB88$150271,547 \mathrm{p}$.

${ }^{2}$ Ljungblad, D. K., S. E. Moore, J. T. Clarke, and J. C. Bennett. 1987. Distribution, abundance, behavior and bioacoustics of endangered whales in the Alaskan Beaufort and Eastern Chukchi Seas, 1979-86. OCS Study MMS 870039, NOSC Tech. Rep. 1177 to U.S. Minerals Manag. Serv., Anchorage, Alaska, NTIS PB-88$116470,391 \mathrm{p}$.

${ }^{3}$ Canada withdrew from the IWC after enactment of the moratorium on commercial whaling in 1982. Currently, the Department of Fisheries and Oceans (DFO) manages Native subsistence requests to hunt bowheads by issuing licenses (http://www.sararegistry.gc.ca/default. asp?lang=En\&n=D67BEABF-1, accessed 6 Apr. 2015)

${ }^{4}$ Suydam, R. S., and J. C. George. 2012. Subsistence harvest of bowhead whales (Balaena mysticetus) by Alaskan Eskimos, 1974 to 2011. Pap. SC/64/AWMP8 pres. to IWC Sci. Committ., May 2012, $13 \mathrm{p}$. al., 1986; Landino et al., 1994). During the spring, most of the migration appears to be a steady flow of whales traveling from the Chukchi Sea to the Beaufort Sea; however, Carroll et al. (1987) reported what appeared to be feeding behavior (i.e., frequent turns) by some whales. Bowhead whales with mud on their dorsal surfaces were also seen during the spring migration near Barrow, indicating that they were near the sea bottom, presumably feeding on epibenthic prey (Mocklin et al., 2012).

Braham et al. (1979) stated that Eskimo whalers had occasionally seen bowhead whales near Point Barrow during the summer, some of which were feeding east of Point Barrow close to shore. In 1989, bowhead whale feeding activity was reported off Barrow from late July to mid-August (George and $\mathrm{Carroll}^{5}$ ). Moore (1992) compiled additional records of bowhead whales in the northeastern Chukchi Sea, comprising 26 sightings that occurred from late July to early September between 1975 and 1991. These sightings indicated that bowhead whales may occupy areas near Barrow during the summer months.

In the early 2000 's, local hunters reported bowhead whales feeding in echelon formation (i.e., animals lined up in a v-shaped pattern, head to tail) near Barrow in late August (George et al. ${ }^{6}$ ). Whales with muddy heads and open mouths and lunge feeding were also observed in early September in 2005 and 2006 (Moore et al., 2010a, b). These observations suggested a need for a more systematic, scientific approach to assess the relative scale of feeding and the consistency of this behavior relative to season, year, age-class, etc., together with relevant ecological pa-

\footnotetext{
${ }^{5}$ George, J. C., and G. M. Carroll. 1989. August sightings of bowhead whales in the Point Barrow to Cape Simpson region. Unpubl. ms., Memorandum to Benjamin P. Nageak dated 21 August 1989. Avail. at North Slope Borough, Dep. Wildl. Manag., P.O. Box 69, Barrow, Alaska, 99723.

${ }^{6}$ George, J. C., S. Moore, W. Koski, and R. Suydam. 2006. Opportunistic photo identification survey: Barrow autumn 2005. Abstr. pres. at Workshop II: Bowhead whale stock structure studies in the Bering, Chukchi, and Beaufort Seas (BCBS) 21-22 March 2006, Seattle, Wash.
}

rameters, such as bathymetry, currents, temperatures, ice conditions, and prey availability.

The Bowhead Whale Feeding Ecology Study (BOWFEST) was initiated in May 2007 through an interagency agreement (formal title: "The bowhead whale feeding variability in the western Beaufort Sea: feeding observations and oceanographic measurements and analyses") between the U.S. Department of the Interior's Minerals Management Service (MMS, now the Bureau of Ocean Energy Management, BOEM) and the Alaska Fisheries Science Center's National Marine Mammal Laboratory (NMML, now Marine Mammal Laboratory, MML). The goal of this 5-year study was to facilitate future oil and gas development-related mitigation by estimating relationships among bowhead whale prey, oceanographic conditions, and bowhead whale feeding behavior in the western Beaufort Sea, with emphasis on identifying predictable aspects in those relationships. The study focused on late summer oceanography and prey densities relative to bowhead whale distribution over continental shelf waters between the coast and lat. $72^{\circ} \mathrm{N}$, and between long. $152^{\circ} \mathrm{W}$ and $157^{\circ} \mathrm{W}$, which is north and east of Point Barrow, Alaska. Projects were timed to end at least one week before the bowhead whale subsistence hunt commenced.

The BOWFEST study included several components. Aerial surveys and passive acoustic monitoring provided information on the spatial and temporal distribution of bowhead whales in the study area. Oceanographic sampling identified sources of zooplankton prey available to whales on the continental shelf and the association of this prey with physical (hydrography, currents) characteristics which may affect mechanisms of plankton aggregation. Prey distribution was characterized by examining temporal and spatial scales of the hydrographic and velocity fields in the study area, particularly relative to oceanic frontal features.

Reports compiling aerial survey data and other components of BOW- 
FEST (passive acoustics, oceanography, tagging, small boat surveys, and stomach analyses) were published annually to the MML website ${ }^{7}$ for each year (2007-11). Results of this research may help explain the increased occurrence of bowhead whales feeding in the western Beaufort Sea (U.S. waters), west of the typical summer feeding aggregations in the Canadian Beaufort Sea. Increased understanding of bowhead whale behavior and distribution is needed to minimize potential impacts from human development in the Arctic. Information from this study will be used by BOEM for pre- and post-lease analysis and documentation under the National Environmental Policy Act (NEPA) for Beaufort and Chukchi Sea Lease Sales.

Here we present results from the 5 years of aerial survey data acquired during late summer, 2007-11. The BOWFEST aerial survey included a combination of systematic transects and photography to document patterns and variability in the occurrence of individual bowhead whales as well as provide descriptions of spatial habitat use within the sample period. Aerial project data were examined to determine whether bowhead whales were traveling through the area or were effectively residents during late summer. Time spent feeding near Barrow in late summer, as well as the consistency of this behavior relative to location within the study area, year, and age class (using whale size as a proxy for age) were also documented.

\section{Methods}

\section{Study Area}

The study area included continental shelf waters and deep submarine canyons between long. $157^{\circ} \mathrm{W}$ and $152^{\circ}$ $\mathrm{W}$ and from the Alaska coastline (barrier islands) to lat. $72^{\circ} \mathrm{N}$ (Fig. 1). This area was divided into a two-part sampling scheme that included tracklines within an inner box $\left(7,276 \mathrm{~km}^{2}\right)$ and an outer box $\left(12,152 \mathrm{~km}^{2}\right)$.

\footnotetext{
${ }^{7}$ Annual reports from the BOWFEST and BWASP projects are available at: http://www. afsc.noaa.gov/nmml/cetacean/bwasp/bowfest. php
}

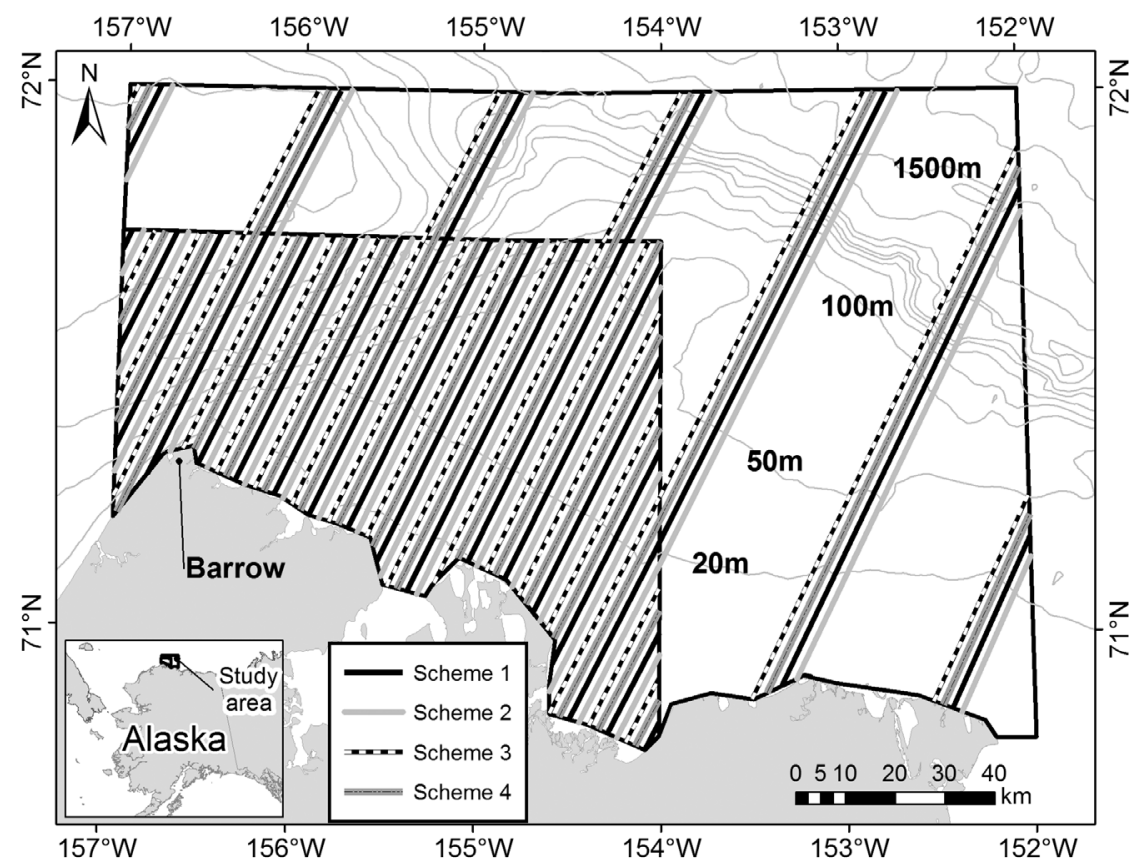

Figure 1.-The four survey schemes for the 2009-11 BOWFEST aerial surveys. Survey schemes differed slightly for 2007 and 2008 (text footnote 7). Most of the effort was concentrated between long. $157^{\circ} \mathrm{W}$ and $154^{\circ} \mathrm{W}$ and between the coastline and lat. $71^{\circ} 44^{\prime} \mathrm{N}$ (the inner box boundaries).

\section{Sampling Scheme}

The design of the sampling scheme was based on 6 years of data (200005) from the Bowhead Whale Aerial Survey Project $\left(\mathrm{BWASP}^{7}\right.$ ) conducted by MMS. These data provided information on bowhead whale relative density (whales per $\mathrm{km}$ surveyed) northeast of Barrow. This helped stratify and ultimately determined the distribution and quantity of survey effort relegated to the inner and outer boxes of the BOWFEST study area. From the BWASP data, the relative density of bowhead whales in the inner box was approximately six times greater than in the outer box. Using equations 7.1, 7.2, and 7.4 from Buckland et al. (1993), the total effort needed in each of the two boxes was calculated to obtain a detection probability sufficient for determining relative densities of whales.

Trackline orientation was based on predetermined oceanographic tracklines which were oriented in a north- easterly direction at $66^{\circ}$ True (i.e., perpendicular to the generalized coastline). The study area contained approximately $5,011 \mathrm{~km}$ of trackline, of which $3,554 \mathrm{~km}$ were in the inner box and $1,457 \mathrm{~km}$ in the outer box (Fig. 1). Tracklines were flown sequentially west to east in order to minimize the probability of resighting the same whale(s) should the westward migration be underway.

The tracklines in the inner box were spaced $2 \mathrm{~km}$ apart while lines in the outer box were $8 \mathrm{~km}$ apart. The placement of the first (most westward) survey line in the inner box (closer to Barrow) was determined by random selection. The same random value to calculate placement of the first line in both boxes was purposely used to align the tracklines in the inner and outer boxes of the study area (Fig. 1). This method simplified flight logistics and minimized transit time between tracklines. Subsequent tracklines were parallel to the first trackline.

Sampling schemes were devised 
by shifting the trackline array short distances to the east or west, removing the likelihood that any tracklines would be flown twice within a season. The first scheme (Scheme 1) was created by selecting the first line from the west side of the study area and every fourth line thereafter. The three remaining schemes were created using the same method, with the second through fourth lines from the west side of the study area. As a result, tracklines for each scheme were spaced approximately $8 \mathrm{~km}$ apart in the inner box of the study area (Fig. 1).

\section{Survey Protocol}

The BOWFEST aerial survey aircraft was a NOAA Twin Otter. ${ }^{8}$ These aircraft have twin turbine engines, high wings, and approximately $5 \mathrm{~h}$ of flying endurance. Two large bubble windows provided views ahead of and beneath the plane for the left- and right-side observers. An open belly window/camera port allowed for vertical photography. Communication among observers, pilots, and the data recorder occurred via an intercom system. Aircraft speed was approximately $185 \mathrm{~km} / \mathrm{h}$ (100 knots). Survey altitude was $310 \mathrm{~m}(1,000 \mathrm{ft})$; most photography passes were between $210 \mathrm{~m}$ (700 $\mathrm{ft})$ and $240 \mathrm{~m}(800 \mathrm{ft})$.

During flight, effort was categorized as deadhead (transiting between tracklines or locations), trackline (systematic search along designated transects), circling (breaking from the trackline mode to investigate a sighting), or photo mode (circling with the specific intent to collect photographs of whales).

The data recorder used a custombuilt aerial survey software program installed on a laptop computer which interfaced with a portable global positioning system (GPS-Garmin 76 CSx). The program saved sighting information, weather parameters, effort (on or off), crew position, and photo data into an Access database. Position information (latitude, longitude,

\footnotetext{
${ }^{8}$ Mention of trade names or commercial firms does not imply endorsement by the National Marine Fisheries Service, NOAA.
}

speed, altitude, and heading) was recorded automatically every $5 \mathrm{sec}$ via the GPS; all other data were entered manually including each start and stop of a trackline. Specific data entries for weather included overall percent ice cover, ice type (categorized using the Observers Guide to Sea Ice ${ }^{9}$ ), sky condition, and sea state (Beaufort scale). Glare, visibility angle, and visibility quality were recorded individually for each side of the aircraft.

To obtain the visibility angle, observers used an inclinometer $\left(0^{\circ}=\right.$ horizontal; $90^{\circ}=$ straight down) to accurately determine the searchable distance out each side of the aircraft. Visibility quality within the given inclinometer angle was one of five subjective categories from excellent to useless; for example, a record of " $20^{\circ}$ good" meant that from the trackline out to $20^{\circ}(0.8 \mathrm{~km})$, sighting conditions were good, and farther from the trackline $\left(<20^{\circ}\right)$ the visibility worsened and was not recorded. Unsurveyed areas (i.e., off effort) included portions of the trackline where both observers rated visibility quality as poor or useless. All marine mammal sightings included date, time, observer, inclinometer angle, group size, reaction to plane, and species. For bowhead whale sightings, observers also reported calf number, travel direction, sighting cue, dominant behavior, and group composition. Any vessels within the study area were also noted.

Immediately upon sighting a marine mammal, the observer reported group size and species to the data recorder. If the sightings occurred ahead of the aircraft an inclinometer angle and any observable reaction to the aircraft were recorded as the aircraft came abeam of the sighting. When a whale appeared to be swimming at a steady speed (i.e., not feeding, resting, or displaying any other type of cetacean behavior), it was recorded as "traveling," and a swim direction was given relative to an analog clock (aircraft nose is 12 o'clock) and later converted rela${ }^{9} \mathrm{http}: / /$ archive.orr.noaa.gov/book_shelf/695_
seaice.pdf tive to global directions $\left(0^{\circ} \mathrm{T}=\right.$ north $)$. The aircraft deviated from the trackline only when an observer was unable to identify the species of a large cetacean. If bowhead whale sightings occurred while on transect, the trackline was typically completed before going off effort to begin photographic passes. This method allowed for a systematic search effort along tracklines and minimized confusion in reporting sightings while off effort.

\section{Photographic Protocol}

Objectives of the photographic portion of the BOWFEST aerial survey included

1) Examining bowhead images for within year (intrayear) matches and across study year (interyear) matches to determine residency times and site fidelity, respectively;

2) Measuring bowhead lengths to determine age class distribution within the study area; and

3) Noting evidence of bowhead feeding behavior (such as mud on body, open mouth, and fecal plumes).

Photographs were taken through a port in the belly of the aircraft located aft of the landing gear. The port was covered in optical quality glass in 2007; however, glare on the window was problematic, so the glass was removed for the 2008-11 surveys. The photographic system evolved over the course of the BOWFEST study. At minimum, two cameras were used with one dedicated to obtaining images for the age class study (photogrammetry) and the other to document residence times and feeding behavior (photo-identification). Date and time on all cameras were synchronized with the date and time on the GPS unit at the beginning of each survey. To obtain usable images for photogrammetry, it was important to keep this camera level and the lens fixed and focused to near infinity and taped to impede rotation.

In 2007, when both cameras were handheld, the photographer using the small, fixed lens $(55$ or $85 \mathrm{~mm}$ ) strove to hold the camera as level as possi- 
ble (no angling) to obtain usable images for photogrammetry. In 2008 and 2009, the photogrammetry camera was housed in a forward motion compensation $\left(\mathrm{FMC}^{10}\right)$ mount (installed on the port side of the belly window) which used a rocker mechanism to counter the forward velocity of the relative ground speed. In 2010 and 2011, three cameras were installed side by side in an FMC mount. The center camera was prioritized for photogrammetry and the left and right cameras were set to overlap the center camera by $20 \%$ by angling them slightly inward. These cameras were integrated with an autonomous radar altimeter (Honeywell AA300 model) in order to collect precise altitudes each time the cameras were fired. Unlike the handheld cameras, mounted cameras were fired using a custom built data acquisition system that automated the retrieval of data (i.e., altitude, time of camera firing, frame number, aircraft speed, and focal length of the camera lens). A keystroke on the computer triggered cameras to continuously fire so that each consecutive image overlapped the previous photo by $60 \%$, adjusted for altitude.

Cameras recorded in RAW format, 21.0 megapixels (5616 x 3744) images and were set to shutter priority (1/1000 sec) and ISO 400-800. After breaking trackline effort, passes were flown over each bowhead group until the observers were confident that most whales in the area had been photographed. During each photographic pass, the forward observer provided a countdown to alert the photographer(s) and data recorder when a whale was about to appear under the aircraft.

Each year, calibration targets were photographed using the same cameras and lenses used to photograph bowhead whales. A land target was used in all years, and in 2008 and 2009, a floating water target was added to look for possible discrepancies between radar altimeter performance over land and water (Mocklin et al., 2010). Alti-

\footnotetext{
${ }^{10} \mathrm{http}: / / \mathrm{www}$.aerialimagingsolutions.com/fmcmount.html
}

tudes for photogrammetric passes were at $30.5 \mathrm{~m}(100 \mathrm{ft})$ intervals ranging from $152 \mathrm{~m}(500 \mathrm{ft})$ to $457 \mathrm{~m}(1,500$ $\mathrm{ft}$ ), weather permitting. Measurements from the photographs provided a linear regression correction factor for the altimeter readings. This correction factor was then applied to photographs of bowhead whales used in the photogrammetric study.

After each survey, all photographs were geo-referenced using Robo$\mathrm{GEO}^{11}$, and RAW images were converted to TIFF (2007-09) or JPG (2010-11). Once geo-referenced, all images and associated metadata were sent to LGL, Inc. for analysis of whale lengths (Koski et al., 1992; 2006). Only images assigned grades of 1-6 were used in the photogrammetric analysis (Koski et al., 2006).

Processing for photo-identification of individual whales began with cropping and labeling of images. Whale images were scored for quality and identifiability (Rugh et al., 1998). Quality scores of 1+ (best), 1-, 2+, 2- or 3 (worst) were assigned to four zones on the whale's body: rostrum, mid-back, lower back, and flukes. A zone scored as 3 was considered inadequate for purposes of reidentifying a whale. Identifiability scores for each zone included $\mathrm{H}+$ or $\mathrm{H}$ - (highly marked), M+ or M- (moderately marked), U+ or U- (unmarked), or X (meaning the zone was not depicted clearly enough in the photo to determine mark status). Scores of X almost always corresponded to quality 3 .

\section{Data Analysis}

Distribution maps for all cetacean sightings were created using ArcGIS 10.1 (ESRI, Redlands, CA, USA). Bowhead whale sightings were linked to a raster bathymetry file (name: IBCAO_V3_500m_RR; Jakobsson et al., 2012) to determine depths (in meters) associated with each sighting. Trackline data were analyzed by day and scheme for each survey year. Segments of on-effort trackline with respective length were linked to each

\footnotetext{
${ }^{11} \mathrm{http}: / /$ www.robogeo.com/home/
}

cetacean sighting that had an inclinometer angle.

Abundance estimates and sighting rates were computed for the cetacean species most frequently encountered during the study: bowhead whales, gray whales, Eschrichtius robustus; and beluga whales, Delphinapterus leucas, using distance sampling methods (Buckland et al., 2001, 2004) as implemented in the Mark-Recapture Distance Sampling (mrds) package (Laake et al., 2007) for R (R Development Core Team, 2008). Both conventional (CDS) and multiple covariate distance sampling (MCDS) approaches were used. To increase the sample size when fitting the detection function, sightings from all years were combined with additional-effort sightings from the transit legs.

To improve the fit of the detection functions, the perpendicular distance data for bowhead whales were truncated at $6 \mathrm{~km}$ and binned into $0.5 \mathrm{~km}$ bins to $3 \mathrm{~km}$ and then $1 \mathrm{~km}$ bins to 6 $\mathrm{km}$. It was not necessary to truncate the perpendicular distance data for beluga or gray whales. The perpendicular distance data for beluga whales was binned into $0.2 \mathrm{~km}$ bins and for gray whales into $0.25 \mathrm{~km}$ bins to 1.5 $\mathrm{km}$ and $0.75 \mathrm{~km}$ thereafter.

Five covariates were explored: sea state, group size (as square root), observer, glare, and sky condition. For gray whales, the four observers with seven or fewer sightings were combined into a single category and the sky variables of light fog, low ceiling, and precipitation were combined into a single category. Hazard-rate and half-normal models were fit without covariates, and with all possible combinations of 1-5 covariates, resulting in 64 candidate models for each species.

The best-fit model for the detection function was selected using Akaike's Information Criteria (AIC) which seeks to maximize the likelihood and minimize the number of model parameters (Burnham and Anderson, 2002). Models with $\triangle \mathrm{AIC} \leq 2$ are considered well supported by the data and are presented here for comparison, but densi- 
Table 1.-Survey days, flight hours, and percent time spent on effort on trackline (in parentheses) during BOWFEST aerial surveys, late August to mid-September during the period 2007-11. Black boxes depict survey days; gray boxes depict days the aircraft and crew were available but precluded from flying due to weather (fog (F), low cloud cover (LC <500 ft ceilings), winds (W >20 kts),) rain (R), snow (S)), or mechanical issues (MI).

\begin{tabular}{|c|c|c|c|c|c|}
\hline & & & Year & & \\
\hline Day & 2007 & 2008 & 2009 & 2010 & 2011 \\
\hline
\end{tabular}

\begin{tabular}{|c|c|c|c|c|c|}
\hline Day & 2007 & 2008 & 2009 & 2010 & 2017 \\
\hline 22-Aug & LC & & & & \\
\hline 23-Aug & $6.7(38 \%)$ & & & & \\
\hline 24-Aug & $3.8(21 \%)$ & & & & \\
\hline 25-Aug & F/LC & & & & \\
\hline 26-Aug & LC/W & & & & $2.0(0 \%)$ \\
\hline 27-Aug & no aircraft & LC/W & & & $\mathrm{F}$ \\
\hline 28-Aug & no aircraft & LC/W & & & $\mathbf{F}$ \\
\hline 29-Aug & no aircraft & $4.9(35 \%)$ & & & $\mathbf{F}$ \\
\hline 30-Aug & no aircraft & $3.9(25 \%)$ & W & & $\mathbf{F}$ \\
\hline 31-Aug & no aircraft & LC/W & w & no fuel & $\mathbf{F}$ \\
\hline 1-Sept & no aircraft & LC/W & W & $0.9(0 \%)$ & $F$ \\
\hline 2-Sept & no aircraft & W & $5.7(46 \%)$ & no fuel & $3.2(35 \%)$ \\
\hline 3-Sept & no aircraft & F/W & W/R & F/LC/R & $\mathrm{F}$ \\
\hline 4-Sept & no aircraft & LC & $4.3(36 \%)$ & $\mathbf{F}$ & $\mathbf{F}$ \\
\hline 5-Sept & F/LC & $6.3(39 \%)$ & w & $\mathbf{F}$ & $6.9(59 \%)$ \\
\hline 6-Sept & $4.1(1 \%)$ & $6.4(36 \%)$ & W/S & $5.3(48 \%)$ & W \\
\hline 7-Sept & $5.5(46 \%)$ & R/F/LC & $4.4(7 \%)$ & F/LC & $4.2(73 \%)$ \\
\hline 8-Sept & LC & R/F/LC & F/LC/R/S & $3.9(44 \%)$ & $4.8(57 \%)$ \\
\hline 9-Sept & $2.5(53 \%)$ & R/F/LC & F/LC/R/S & $F$ & $4.5(54 \%)$ \\
\hline 10-Sept & LC & R/F/LC & F/LC/R/S & $\mathbf{F}$ & w \\
\hline 11-Sept & $8.2(57 \%)$ & $6.7(46 \%)$ & F/LC/R/S & $\mathbf{F}$ & w \\
\hline 12-Sept & LC/F/W & F/LC & F/LC/R/S & $9.5(62 \%)$ & $8.2(58 \%)$ \\
\hline 13-Sept & aircraft maintenance & $10.9(49 \%$ & F/LC/R/S & $2.1(26 \%)$ & $8.0(45 \%)$ \\
\hline 14-Sept & & MI & $1.0(0 \%)$ & F/W & $4.3(63 \%)$ \\
\hline 15-Sept & & $2.4(18 \%)$ & $2.7(33 \%)$ & $4.4(60 \%)$ & w \\
\hline 16-Sept & & $1.1(40 \%)$ & LC & LC/W & $0.7(39 \%)$ \\
\hline 17-Sept & & w & LC & $5.2(52 \%)$ & \\
\hline 18-Sept & & & & $1.6(0 \%)$ & \\
\hline Total & 30.8 (39\%) & $42.6(39 \%)$ & $18.0(30 \%)$ & 32.9 (49\%) & $46.8(53 \%)$ \\
\hline
\end{tabular}

ty and abundance were computed with the best-fit model. On-effort sightings were separated by strata for estimating group size, sighting rates, density, and abundance. Data were not collected to determine animals missed on the trackline (perception bias) or animals submerged when the plane passed (availability bias). Therefore, corrections were not made for these biases and $\mathrm{g}(0)$, the sighting probability on the trackline, was assumed to be 1 .

Distributions were also compared among these three cetacean species. Each species distribution each year was weighted by group size using 1SD "directional distribution" ellipses in ArcGIS which captured approximately $68 \%$ of the sightings. Additional analyses were conducted on sightings in the inner box then compared to combined inner and outer box sightings for all years to determine if distributions were significantly different.

To describe the presence or absence of sightings as a function of environmental, or explanatory, variables, all bowhead, gray, and beluga whale sightings within the inner box were linked to bathymetric depth (BATHY), bathymetric slope (SLOPE), distance from the shelf break (100 m isobaths - DISTSHELF), and distance from shore (DISTSHORE). The resolution of all spatial data layers in ArcGIS was $100 \times 100 \mathrm{~m}$. For each whale species, random locations were generated to match the number of sightings within the inner box.

To examine the structure within the data, a logistic regression model was employed. After examining the variables for colinearity, we used a backward elimination method to assess the significance of the environmental variables in predicting habitat use. AIC was used to select the final model for each of the three species. The diagnostic accuracy of each of these models was determined using a receiver operating characteristic (ROC) curve which is able to detect a signal in the presence of noise. The area under the ROC curve (AUC) ranges from 0 (no discrimination ability) to 1 (perfect discrimination ability against false positives and false negatives). Values greater than or equal to a threshold value ( 0.40 for beluga, 0.51 for bowhead, and 0.61 for gray whales) were classified as preferred habitat.

Swim direction at the time of each sighting was compared for all bowhead whales with travel noted as the primary behavior. A Rayleigh uniformity test (KCS, 2012), run in the software program Oriana, determined whether clustering around a mean swim direction occurred within each survey year. Feeding behaviors (mud on the whale, mouth open, and fecal plume) were reported by the observers and documented during the photography effort. We examined percentages of feeding behavior reported by observers and captured photographically each year. We also mapped the locations of sightings and photographs documenting these behaviors.

For residency times, all images were compared to determine if individual whales were photographed multiple times over multiple days (multiple images of an individual obtained within a single day were considered to be a single sample). Following intrayear comparisons, whale images were compared across all BOWFEST years to look for evidence of seasonal site fidelity. We also noted if any matched whales appeared to be feeding.

Using photogrammetric lengths, bowhead whales were sorted into specific age classes (calf, juvenile, and adult per Koski et al. (1992, 2006)) to help determine age structure within the study area over the five-year period. Length data were binned and graphed by year and overall. We also present length data for the subset of whales that appeared to be feeding.

\section{Results and Discussion}

\section{Survey Effort}

Aerial surveys were conducted in the BOWFEST study area from the end of August to mid-September during the period 2007-11 for a total of 171.1 hours flown. Most in-flight, oneffort survey time was spent on trackline (Table 1). A total of 10.3 hours of survey time ( $6.3 \%$ of all flight time) 
Table 2. - Survey trackline effort during BOWFEST aerial surveys within the inner and outer boxes of the study area from late August to mid-September during the period 2007-11

\begin{tabular}{lcccc}
\hline Year & $\begin{array}{c}\text { Inner box } \\
(\mathrm{km} \text { surveyed })\end{array}$ & $\begin{array}{c}\text { Inner box } \\
(\% \text { covered })\end{array}$ & $\begin{array}{c}\text { Outer box } \\
(\mathrm{km} \text { surveyed })\end{array}$ & $\begin{array}{c}\text { Outer box } \\
(\% \text { covered })\end{array}$ \\
\hline 2007 & 2071.2 & $58 \%$ & 208.6 & $4 \%$ \\
2008 & 2637.3 & $74 \%$ & 445.5 & $9 \%$ \\
2009 & 1007.0 & $28 \%$ & 0.0 & $0 \%$ \\
2010 & 2653.0 & $75 \%$ & 407.5 & $8 \%$ \\
2011 & 4134.4 & $116 \%$ & 476.5 & $10 \%$ \\
\hline
\end{tabular}

was in poor or useless viewing conditions, and there were 57 days without surveys due to weather $(56 \%$ of all days when the aircraft was available for flying).

On flight days, $56 \%$ of the survey effort was over calm seas with few whitecaps (Beaufort Sea States 3 or lower). Sea states of 3 and lower are considered optimal for detecting most marine mammal species; however, observers reported $91 \%$ of survey effort as "fair" or better, suggesting despite higher sea states the observers remained confident that bowhead whales could be detected. The greatest percentage of effort was focused within the inner box of the study area (Table 2, Fig. 2).

\section{Sightings}

Marine mammals observed within the study area were identified to species whenever possible (Table 3 ). Over 1,000 sightings of marine mammals were recorded during the 5-year study. In addition to the focal species (bowhead whales) observed species included gray whales, one humpback whale, beluga whales, ringed seals, Phoca hispida; bearded seals, Erignathus barbatus; walrus, Odobenus rosmarus; and polar bears, Ursus maritimus. Small pinnipeds, such as ringed seals and spotted seals, Phoca largha, were often difficult to differentiate and identify to species given the relatively high survey altitude of $310 \mathrm{~m}(1,000$ ft) (Table 3).

Beluga whales were the only odontocetes observed (Fig. 3). Though not seen during BOWFEST aerial surveys, harbor porpoise, Phocoena phocoena, also occur off Barrow (Suydam and George, 1992), and occasionally killer whales, Orcinus orca (Braham and Dahlheim, 1982; Clarke et al. ${ }^{12}$ ). Beluga whales were seen in all years except 2009, and although survey effort was limited that year, sighting numbers were also low the preceding and following year. In general, beluga whales were found in slope waters and over the deeper waters of Barrow Canyon; however, in 2011, groups were also observed swimming near barrier islands (Fig. 3).

Three species of baleen whales were seen during BOWFEST: bowhead, humpback, and gray whales. In 2009, a lone humpback whale associated with a group of gray whales was observed in shelf waters off Point Barrow (Fig. 4). Gray whales were present during every survey year, and sighting numbers were consistent year to year with the exception of 2010 when their numbers were at their lowest and bowhead whales at their highest (Table 3). Almost all gray whale sightings occurred on the $50 \mathrm{~m}$ isobath along Barrow Canyon (Fig. 4).

Bowhead whale presence and sighting numbers were variable from year to year (Table 3). There was no apparent increase in bowhead sightings during the survey period as might be expected with the onset of the fall migration (Table 4). Most sightings occurred over continental shelf waters east of Point Barrow (Fig. 5). In 2007, the aerial team found whales in shelf waters (on the $20 \mathrm{~m}$ isobath) on 2 days in late August, but none

${ }^{12}$ Clarke, J. T., C. L. Christman, A. A. Brower, and M. C. Ferguson. 2013. Distribution and relative abundance of marine mammals in the northeastern Chukchi and western Beaufort seas, 2012. Annu. Rep., OCS Study BOEM 2013-00117, 364 p., Natl. Mar. Mammal Lab., Alaska Fish. Sci. Cent., NMFS, NOAA, 7600 Sand Point Way NE, F/AKC3, Seattle, WA 98115-6349 (http://www.afsc.noaa.gov/nmml/ PDF/COMIDA-2012-Report.pdf) were found in September. In 2008, aerial observations included a few whales scattered in Barrow Canyon, large groups along the canyon shelf break north of Barrow, some groups along the $20 \mathrm{~m}$ isobath on the shelf, and small numbers in deeper waters to the east. In 2009, most bowhead whale sightings occurred along the $20 \mathrm{~m}$ isobath, with a few whales in Barrow Canyon and along the shelf break near Barrow. In 2010, there was no inshore-offshore bias in bowhead whale distribution. The aerial team found large numbers of whales near the barrier islands, closer to shore than during any other study year, and spread across the shelf to the slope. In 2011, whales were in Barrow Canyon and deeper waters to the east, not on the shelf. Most sightings in 2011 occurred in waters $>100 \mathrm{~m}$ deep. With sightings binned into four depth ranges (Fig. 6), most bowhead whales were in relatively shallow water; $72 \%$ were in water depths $<30 \mathrm{~m}$ and $80 \%$ in waters $<50 \mathrm{~m}$. The remaining bowhead whales were in waters between 50 and $100 \mathrm{~m}(8 \%)$ and greater than $100 \mathrm{~m}(12 \%)$, the latter largely driven by distribution in 2011.

\section{Abundance}

The detection functions for the best-fit models (minimum AIC) for bowhead, gray, and beluga whales are shown in Figure 7. Table 5 includes all well-supported $(\triangle \mathrm{AIC} \leq 2)$ models compared to the best-fit model for each species. For bowhead whales, the hazard rate model with the square root of group size and observer as covariates was the best-fit model. For gray whales and beluga whales, the halfnormal model with the square root of group size as a covariate were the bestfit models. Group size was the most important variable as it was a covariate in all the models with $\triangle \mathrm{AIC} \leq 2$ for all three species with the exception of one beluga model that had no covariates (Table 5). For bowhead whales, observer was also an important variable and present in all bowhead models with $\triangle \mathrm{AIC} \leq 2$.

Encounter rate, group size, density, 

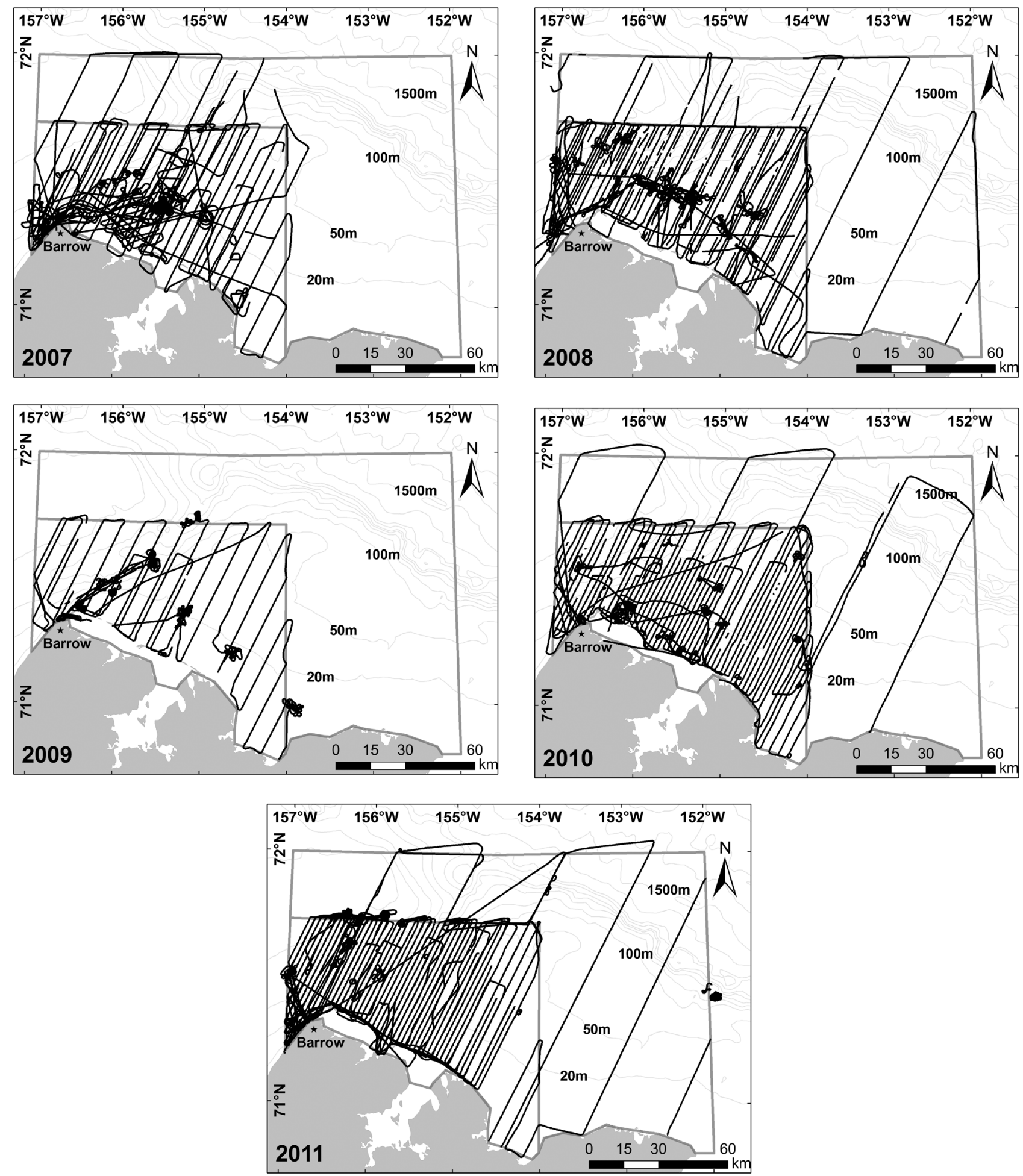

Figure 2.-All search effort, including transect, circling, and photo effort for each BOWFEST aerial survey from late August to mid-September during the period 2007-11. 
Table 3.-Summary of marine mammal sightings and counts made during BOWFEST aerial surveys from late August to mid-September during the period 2007-11. Bowhead whale counts usually increased when off trackline to circle or photograph groups of whales (in parenthesis). Bowhead whales observed during transit between transects were also included in the grand total number.

\begin{tabular}{|c|c|c|c|c|c|c|}
\hline \multirow[b]{2}{*}{ Marine mammal } & \multicolumn{5}{|c|}{ Sightings/count (count after departing trackline to circle) per year } & \multirow[b]{2}{*}{ Total } \\
\hline & 2007 & 2008 & 2009 & 2010 & 2011 & \\
\hline Bowhead whale & $16 / 35(68)$ & $56 / 191(195)$ & $29 / 35(55)$ & $102 / 396(452)$ & $18 / 10(68)$ & 221/667(838) \\
\hline Gray whale & $20 / 29$ & $22 / 39$ & $22 / 30$ & $6 / 10$ & $26 / 34$ & $96 / 142$ \\
\hline Beluga whale & $18 / 30$ & $2 / 2$ & & $2 / 5$ & $95 / 460$ & $117 / 497$ \\
\hline Humpback whale & & & $1 / 1$ & & & $1 / 1$ \\
\hline Ringed seal & $73 / 119$ & $4 / 6$ & $2 / 2$ & $8 / 40$ & & $87 / 167$ \\
\hline Bearded seal & $31 / 89$ & $9 / 9$ & $6 / 6$ & $3 / 3$ & $21 / 22$ & $70 / 129$ \\
\hline Walrus & $65 / 255$ & & $3 / 12$ & $1 / 2$ & & $69 / 269$ \\
\hline Polar bear & $2 / 2$ & $4 / 5$ & & $16 / 23$ & $6 / 6$ & $28 / 36$ \\
\hline Unid large cetacean & & $13 / 13$ & $6 / 7$ & $1 / 1$ & $6 / 9$ & $26 / 30$ \\
\hline Unid small cetacean & & & & & $1 / 1$ & $1 / 1$ \\
\hline Unid pinniped & $10 / 12$ & $86 / 139$ & $25 / 52$ & $61 / 86$ & $117 / 237$ & $299 / 526$ \\
\hline Total & $\overline{235 / 571}$ & $\overline{196 / 404}$ & $\overline{94 / 145(162)}$ & $\overline{200 / 566(553)}$ & $\overline{290 / 779(836)}$ & $1,015 / 2,465(838)$ \\
\hline Sightings $/ \mathrm{km}$ & 0.103 & 0.064 & 0.093 & 0.065 & 0.063 & \\
\hline
\end{tabular}

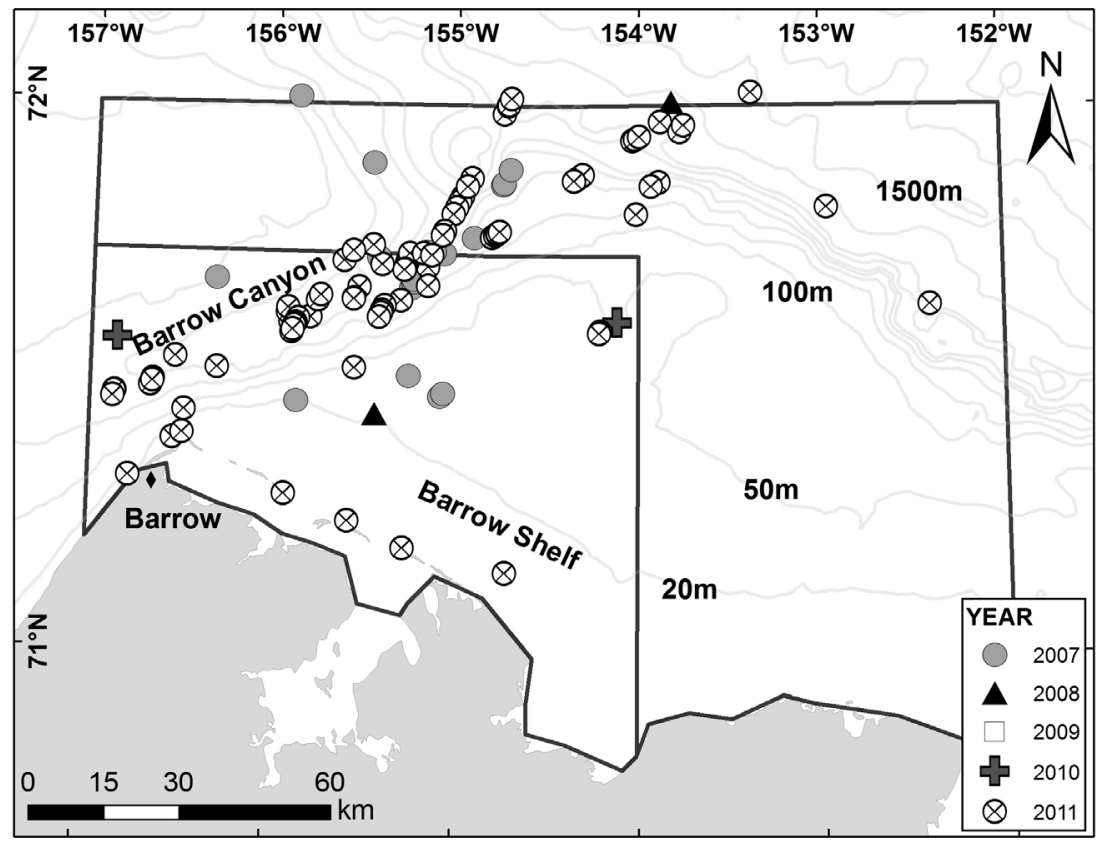

Figure 3.-Locations of beluga whale sightings during BOWFEST aerial surveys from late August to mid-September during the period 2007-11. Note: there were no sightings in 2009.

and abundance were estimated using the best-fit detection function model and are presented in Tables 6 and 7 for each species by year and survey domain. Estimated encounter rates (\#/ $\mathrm{km})$ (Table 6) and density $\left(\# / \mathrm{km}^{2}\right)(\mathrm{Ta}-$ ble 7) for bowhead whales were generally higher in the inner box of the study area in all years. With the exception of 2007, estimated group sizes were $<3$ whales (Table 6). Estimated abundance for the inner box was also the outer box of the study area (2007 and 2011), encounter rates were 2.68.2 times lower in the inner box (Table 6). Estimated abundance in 2007 and 2011, respectively, ranged from 21 $(C V=0.76)$ to $280(C V=0.90)$ (inner vs. outer box ) and $123(C V=0.43)$ to $825(C V=0.75)$ (inner vs. outer box). When not present in the outer box, belugas were rarely encountered in the inner box of the study area (0.0004/ $\mathrm{km}, C V=1)$.

\section{Habitat Preferences}

Habitat partitioning between bowhead and gray whales was evident in all survey years, and among bowhead, gray, and beluga whales in those years when belugas were observed in large numbers (Fig. 8). The standard deviation ellipses show each species occupied a unique region within the study area with slight overlaps occurring in some years. Overall, bowhead distribution was oriented along the barrier islands and $20 \mathrm{~m}$ isobath on the continental shelf and also included parts of the Barrow Canyon and shelf break that were close to shore (Fig. 8). Gray whale distribution oriented along the Barrow Canyon shelf break near the $50 \mathrm{~m}$ isobath; while beluga distribution ellipses centered over Barrow Canyon and offshore slope waters (Fig. 8). This preference for particular depth ranges was similar to that observed during surveys conducted in the 1980's and early 1990's (Clarke et al., 1993; Moore and DeMaster, 1998; Moore et al., 2000). However, ice conditions also appeared to affect bowhead distribution during these earlier years; in particular, heavy ice was associated with whales occupying deeper slope waters (Moore, 2000), which was not a factor during the BOWFEST surveys.

The ROC model examined four specific physical features within the inner box to describe preferred habitat for all three species. For bowhead whales, distance from shore and distance from the shelf break were significant in predicting the presence of bowhead whales $(p<0.01$, Table 8$)$; therefore, their preferred habitat in- 


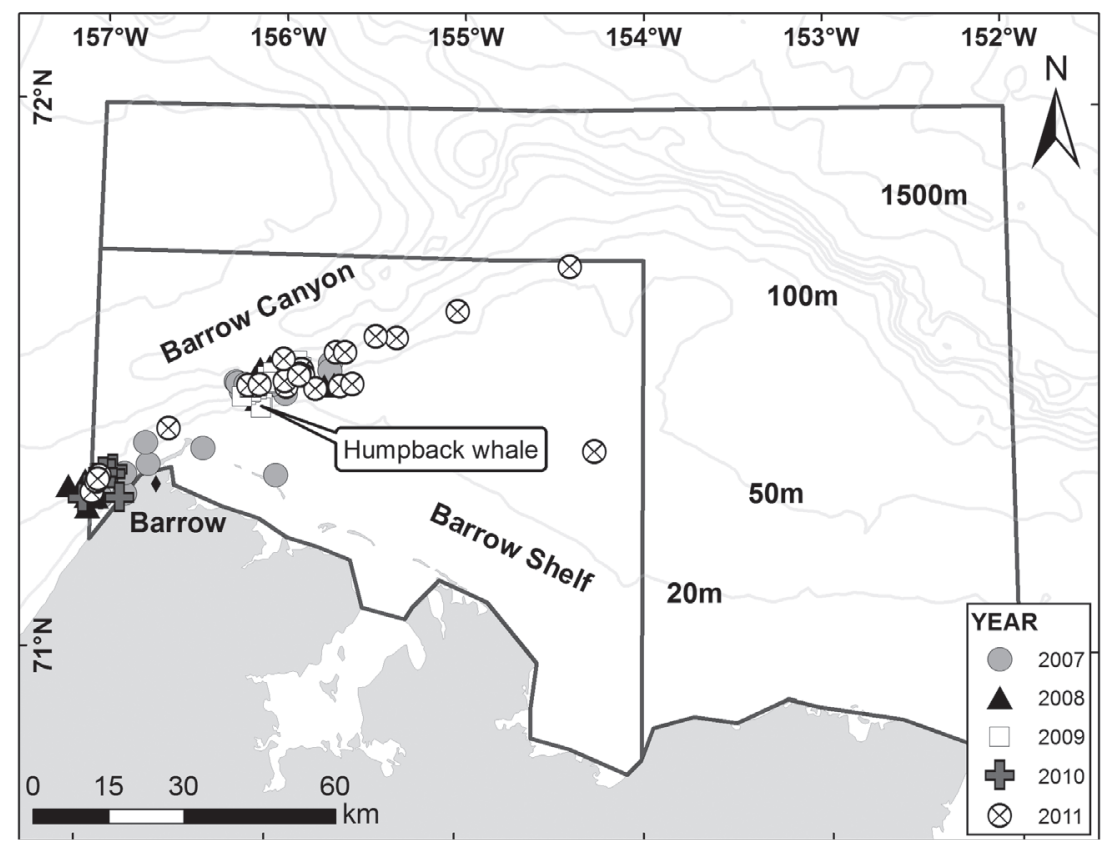

Figure 4.-Locations of a humpback whale and gray whale sightings during BOWFEST aerial surveys from late August to mid-September during the period 2007-11.

Table 4.-Survey days (black boxes) and all on/off trackline bowhead whale sightings and counts (in parentheses) during BOWFEST aerial surveys from late August to mid-September during the period 2007-11. Gray boxes depict days aircraft was available but unable to fly (due to weather or mechanical issues).

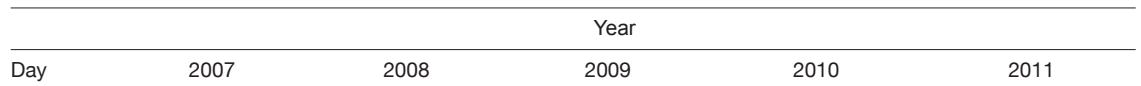

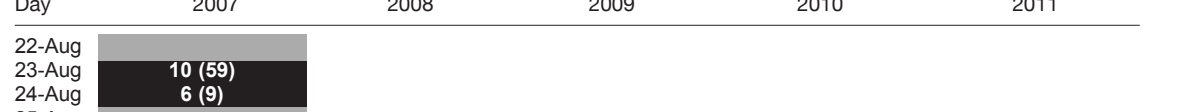

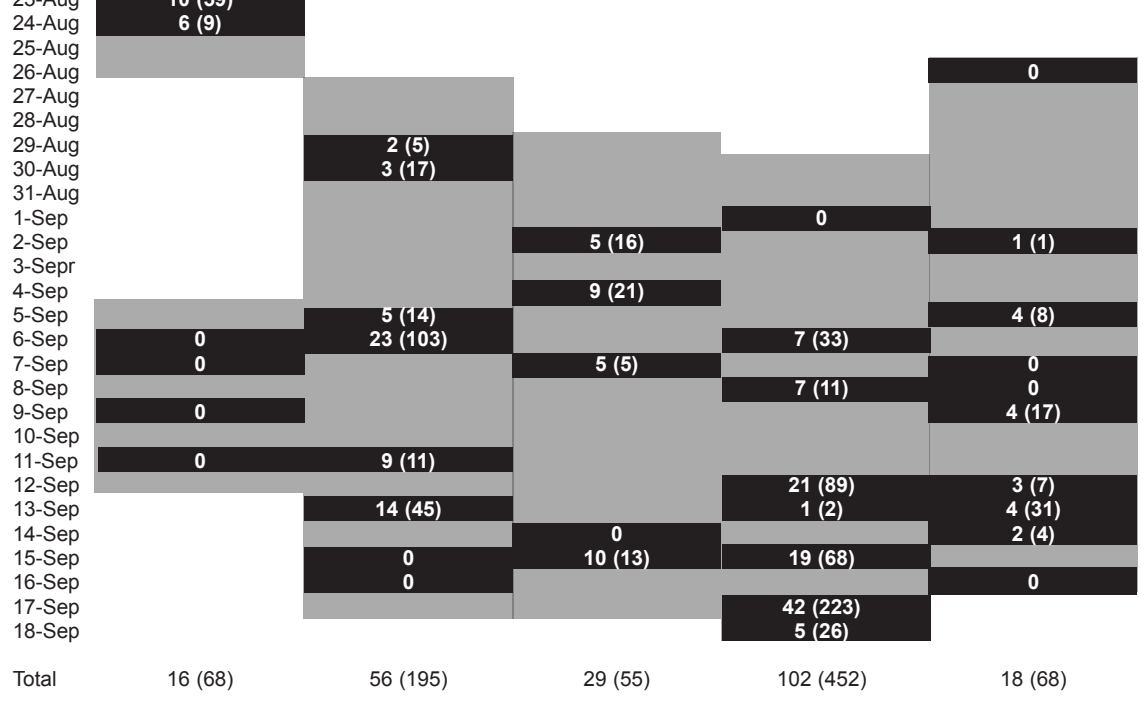

cluded the nearshore region oriented east to west that included parts of Barrow Canyon, the shelf break, and Barrow Shelf (Fig. 9). Although these two parameters were significant in determining preferred habitat, the AUC value was 0.67 , indicating that the model was only able to correctly discriminate between the presence (bowhead sighting) and absence (random points) 67\% of the time. The 0.51 threshold value resulted in approximately $2,576 \mathrm{sq}$. $\mathrm{km}$ of preferred bowhead habitat (38\% of the inner box).

All four parameters were significant in predicting gray whale presence $(p<$ 0.01 , Table 8). Gray whales preferred to be in shallow water that was closer to shore and aligned along the shelf break. A 0.96 value for the AUC indicated that the model was able to correctly classify gray whale presence and absence $96 \%$ of the time. The 0.61 threshold value resulted in $802 \mathrm{~km}^{2}$ of preferred habitat, approximately $12 \%$ of the inner box of the BOWFEST study area (Fig. 9).

Of the four parameters included in the model, only bathymetry was significant in predicting beluga whale presence ( $p<0.01$, Table 8 ). These animals preferred to be in deeper water more than would be predicted at random. An AUC value of 0.82 indicates that the final model correctly discriminated sightings from non-sightings $82 \%$ of the time and resulted in 1,948 sq. $\mathrm{km}$ of preferred habitat or approximately $29 \%$ of the inner box of the BOWFEST study area (Fig. 9), primarily within Barrow Canyon. While there was a large portion of overlap in the predicted habitat for these species, there was clear spatial separation in their preferred habitat (Fig. 8 and 9, last panel).

\section{Behaviors}

The behaviors observed most often were swimming or resting at the surface for most species. The only species, other than bowhead whales, observed feeding within the study area was gray whales. Large mud plumes were often listed as the sighting cue for gray whales. Of the bowhead whale 
behaviors noted by observers, traveling was reported more often than feeding during most years ( $45 \%$ vs. $22 \%$ of all sightings, $n=221$ ). Swim direction was noted for $94 \%$ of the traveling bowhead whales (Table 9).

Presumably, if the fall migration was underway, most whales would be traveling in a westerly direction (between $226^{\circ}$ and $315^{\circ} \mathrm{T}$ ); however, this was not evident in most years (Fig. 10). The sample size in 2007 was too small (only 2 of the 16 sightings noted travel as the primary behavior) to test for significance. In 2008, significantly more bowhead whales traveled in a westerly direction (i.e., about $295^{\circ} \mathrm{T}$; Rayleigh's uniformity test probability $<0.05)$. No significant travel direction was documented in 2009-11.

Aerial observations during the late August to mid-September study period included obvious feeding bouts: observers noted feeding behavior during $7-50 \%$ of sightings among the 5 years of the study; and $15-49 \%$ of photographed whales exhibited feeding behavior in any given year (Fig. 11). Of the individual whales that were visually or photographically identified as feeding, 81-90\%, respectively, were in shelf waters, and the majority of those were clustered around the $20 \mathrm{~m}$ isobath (Fig. 12). More feeding behavior was observed and photographed during years when most sightings occurred on the shelf $(2007,2009,2010)$ (Fig. 12) but not always in years when bowheads were most abundant (Fig. 13). The lowest percent feeding both visually and photographically occurred in 2008 (Fig. 11), the only year whale swim direction was predominately westerly (Table 9, Fig. 10). Feeding behavior, residency times and site fidelity, and age classes of bowhead whales present within the study area were further explored through the photographic component of BOWFEST.

\section{Photographic Effort}

Bowhead whales were photographed on 22 survey days across the five field seasons. In total, 16.7 hours were spent photographing bowhead whales, resulting in 1,605 pictures taken when

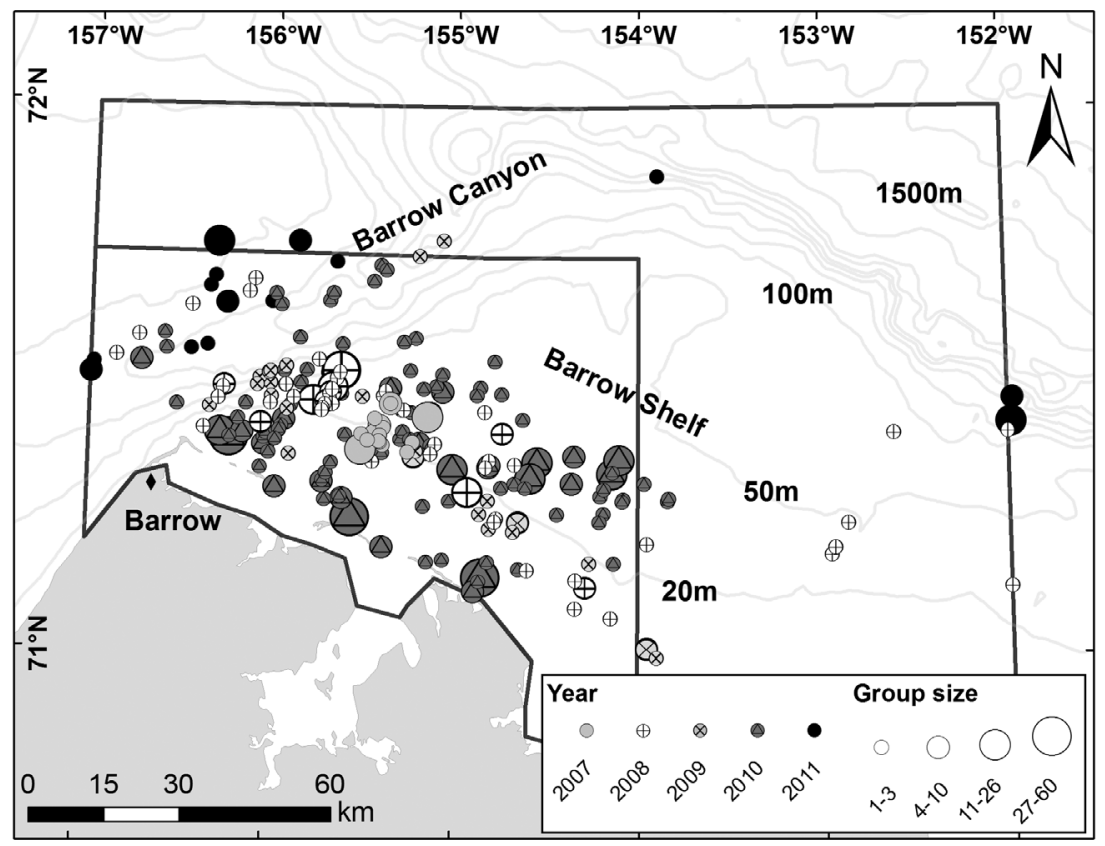

Figure 5.-Locations and group sizes of bowhead whales during BOWFEST aerial surveys from late August to mid-September during the period 2007-11.

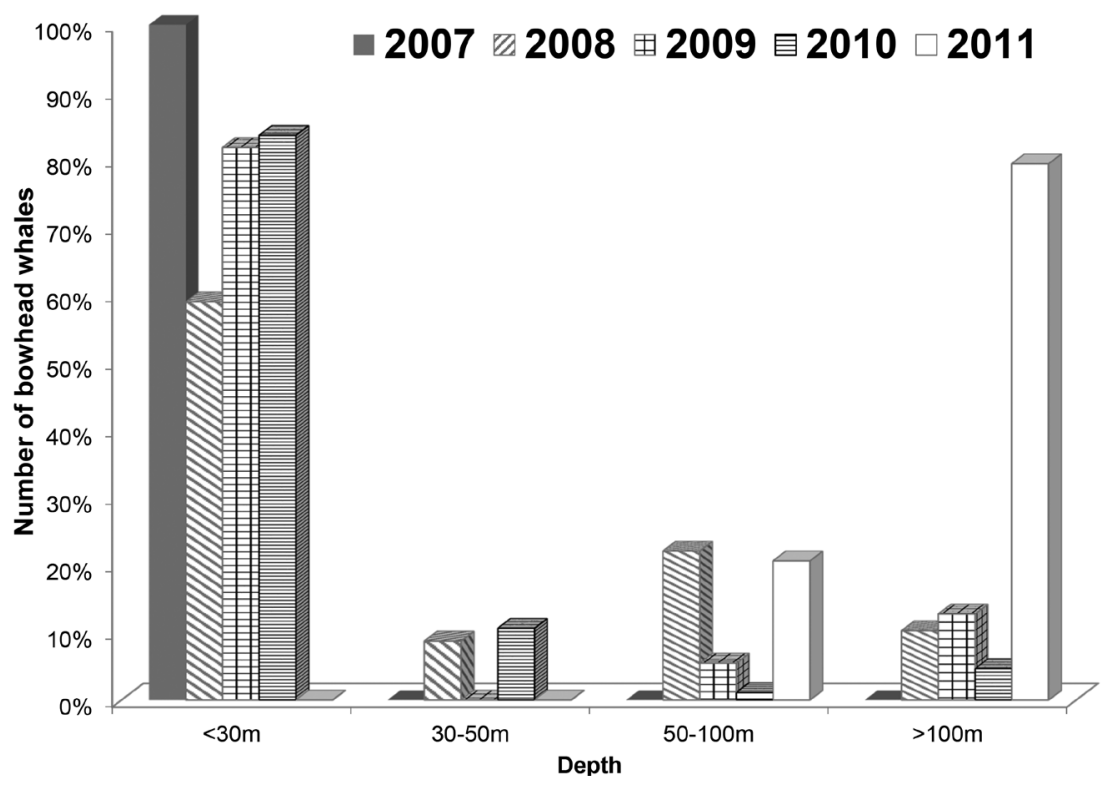

Figure 6.-Depths at which bowhead whales were seen (using counts obtained after departing the trackline to circle: Table 3) during BOWFEST aerial surveys from late August to mid September for the period 2007-11. 
whales were directly beneath the aircraft. Quality ratings of bowhead images indicate that $206(15 \%)$ were of excellent quality (1+ or 1-) in at least one zone on the body (rostrum, midback, lower back, or flukes), 527 (37 $\%)$ were good (2+ or 2-) in at least one zone on the body, and $682(48 \%)$ were not useful (3) in all zones on the body. Photos were considered inadequate usually when a whale was too deep in the water, there was too much splash over the whale's dorsal surface, or the whale was not lying prone in the water.

The 1,605 photographs contained 2,387 images of bowhead whales. Matching and removing duplicate photos from passes left a working set of 1,415 images from which 664 unique whales were identified. Among the 1,415 images used for matching, 33 images $(2 \%)$ were highly marked $(\mathrm{H}+$ or $\mathrm{H}-)$ in at least one zone on the body, 43 images $(3 \%)$ were moderately marked $(\mathrm{M}+$ or $\mathrm{M}-)$ in at least one zone on the body, 667 (47\%) were unmarked (U+ or U-) in at least one zone on the body, and $672(48 \%)$ were useless $(\mathrm{X})$ in all zones on the body.

In addition to whale images, 5.5 flight hours were spent taking photographs of calibration targets. Measured images of the floating targets showed a strong correlation between the digital imagery and true lengths from the targets, indicating that radar altimeter performance does not change significantly whether over land or water (Mocklin et al., 2010). Of the 803 images measured for the photogrammetric length (age) class analysis, 654 were within grades 1-6 (Koski et al., 2006).

Bowhead whale images were categorized as feeding $(n=232,35 \%$ of the sample) when mud was present on the whales' dorsal surface, mouths were open (skim feeding), mud plumes were apparent, or whales defecated (fecal plumes). During all years of the aerial study, muddy whales were photographed (Fig. 11). Mocklin et al. (2012) determined that mud can persist for over 4 hours on the skin of a bowhead whale (based
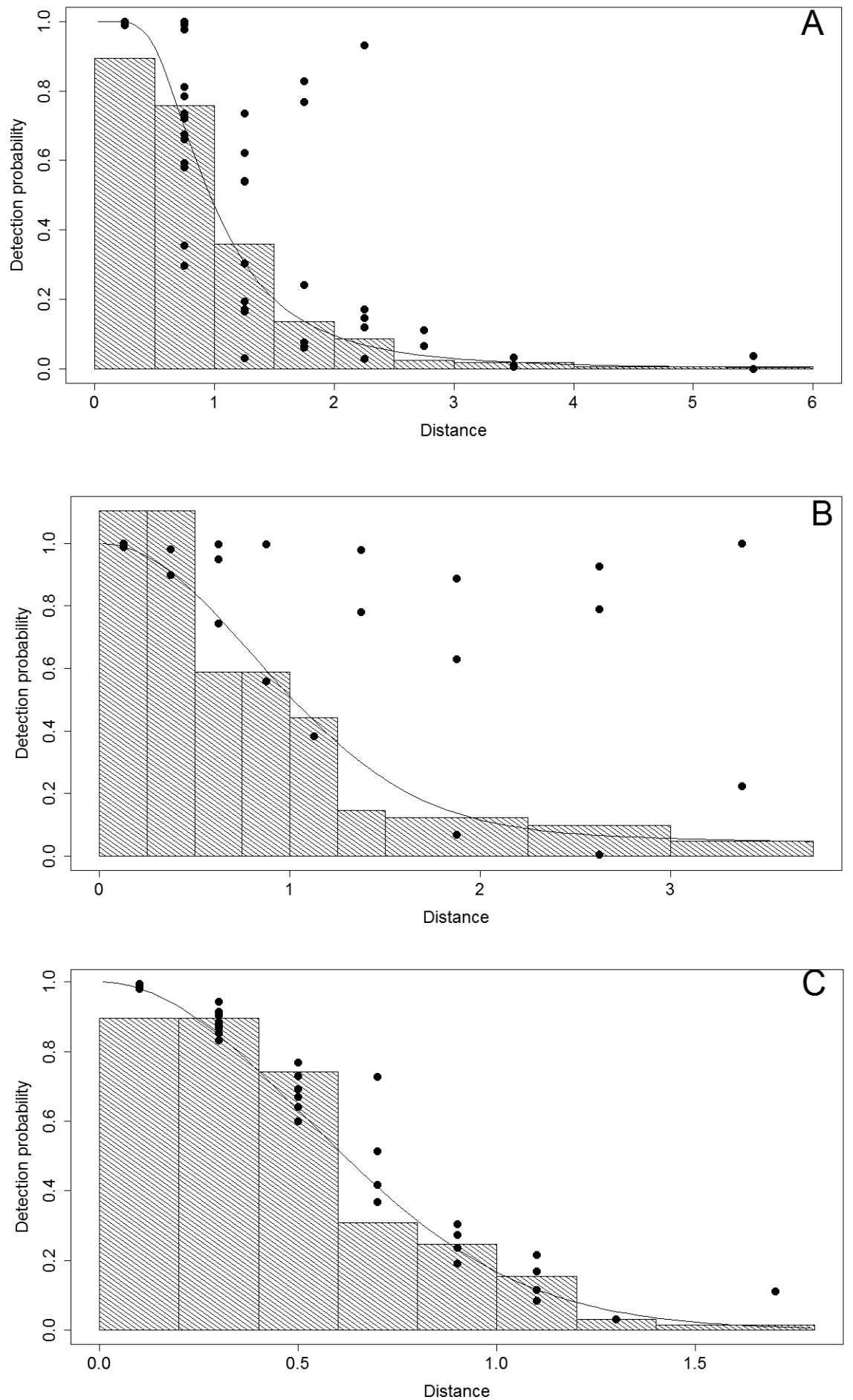

Figure 7.- Histograms of perpendicular distance $(\mathrm{km})$ and fitted detection functions for best-fit model selected by Akaike's Information Criteria (dots represent detection probability for each individual sighting) for (A) bowhead whales, (B) gray whales, and (C) beluga whales during BOWFEST aerial surveys from late $\mathrm{Au}-$ gust to mid-September for the period 2007-11. 
on photo-recaptures), and potentially up to 9 hours or more (based on flow tank tests), depending on swim speed and location on the body. The authors concluded that a whale swimming at 3 $\mathrm{km} / \mathrm{hr}$ could have been muddied $27 \mathrm{~km}$ away from its current location. Even if muddied $27 \mathrm{~km}$ away, 90\% of the whales photographed during BOWFEST would still be within the boundaries of the inner box of the study area (Fig. 12b). An open mouth, however, suggests active feeding at the current location. This behavior was observed in all years but 2008 (Fig. 11).
Table 5. - Best-fit model proposed to fit perpendicular distance data for bowhead, gray, and beluga whales during BOWFEST aerial surveys from late August to mid-September for the period 2007-11. Summary of model selection for well-supported models with Akaike's Information Criteria $(\Delta \mathrm{AIC} \leq 2)$ compared to the best-fit model. Models: $\mathrm{hz}=$ hazard rate and $\mathrm{hn}=$ half normal. Covariates: beaufort = Beaufort sea state, size.sqrt = square root of group size, obs $=$ observer, glare $=$ glare present or absent, $\mathbf{s k y}=$ sky condition, $w_{i}=$ Akaike weight, $P=$ average detection probability, and $\mathrm{CV}=$ coefficient of variation of the average detection probability.

\begin{tabular}{|c|c|c|c|c|c|c|}
\hline Model, covariates & AlC & $\triangle \mathrm{AIC}$ & $w_{i}$ & Parameters & $P$ & $\mathrm{CV}$ \\
\hline \multicolumn{7}{|l|}{ Bowhead whales } \\
\hline$h z$, size.sqrt + obs & 551.69 & 0.00 & 0.310 & 9 & 0.19 & 0.09 \\
\hline hz, size.sqrt + obs + glare & 552.62 & 0.93 & 0.195 & 10 & 0.19 & 0.09 \\
\hline $\mathrm{hz}$, beaufort + size.sqrt + obs & 553.54 & 1.85 & 0.123 & 10 & 0.19 & 0.09 \\
\hline \multicolumn{7}{|l|}{ Gray whales } \\
\hline hn, size.sqrt & 251.82 & 0.00 & 0.135 & 2 & 0.32 & 0.08 \\
\hline hn, size.sqrt + sky & 252.37 & 0.55 & 0.102 & 5 & 0.29 & 0.12 \\
\hline hn, beaufort + size.sqrt & 252.75 & 0.93 & 0.085 & 3 & 0.32 & 0.10 \\
\hline hn, size.sqrt + obs & 253.21 & 1.39 & 0.067 & 4 & 0.31 & 0.13 \\
\hline $\mathrm{hr}$, size.sqrt & 253.38 & 1.56 & 0.062 & 3 & 0.31 & 0.13 \\
\hline hn, size.sqrt + glare & 253.60 & 1.78 & 0.055 & 3 & 0.32 & 0.09 \\
\hline \multicolumn{7}{|l|}{ Beluga whales } \\
\hline hn, size.sqrt & 367.64 & 0.00 & 0.184 & 2 & 0.37 & 0.08 \\
\hline hn (no covariates) & 368.71 & 1.06 & 0.108 & 1 & 0.37 & 0.07 \\
\hline hn, size.sqrt + glare & 369.55 & 1.91 & 0.071 & 3 & 0.37 & 0.08 \\
\hline hn, beaufort + size.sqrt & 369.55 & 1.91 & 0.071 & 3 & 0.37 & 0.08 \\
\hline
\end{tabular}

Table 6.-Number of sightings ( $n$ ), encounter rates (ER, \#/km), encounter rate coefficient of variation (ER CV), estimated group size (ES), and estimated group size coefficient of variation (ES CV) for bowhead, gray, and beluga whales by year and domain during BOWFEST aerial surveys from late August to mid-September.

\begin{tabular}{|c|c|c|c|c|c|c|c|c|c|c|c|c|c|c|c|}
\hline \multirow[b]{2}{*}{$\begin{array}{l}\text { Year and } \\
\text { Domain }\end{array}$} & \multicolumn{5}{|c|}{ Bowhead whale } & \multicolumn{5}{|c|}{ Gray whale } & \multicolumn{5}{|c|}{ Beluga whale } \\
\hline & $n$ & ER & ER CV & ES & ES CV & $n$ & ER & ER CV & ES & ES CV & $n$ & ER & ER CV & ES & ES CV \\
\hline \multicolumn{16}{|l|}{2007} \\
\hline Inner & 5 & 0.0025 & 0.71 & 4.60 & 0.58 & 9 & 0.0044 & 0.43 & 1.67 & 0.22 & 5 & 0.0025 & 0.66 & 1.60 & 0.37 \\
\hline Outer & 0 & 0 & - & 0 & - & 0 & 0 & - & 0 & - & 4 & 0.0202 & 0.83 & 1.50 & 0.33 \\
\hline Total & 5 & 0.0022 & 0.71 & 4.60 & 0.58 & 9 & 0.0040 & 0.44 & 1.67 & 0.22 & 9 & 0.0040 & 0.51 & 1.56 & 0.24 \\
\hline \multicolumn{16}{|l|}{2008} \\
\hline Inner & 45 & 0.0178 & 0.23 & 2.47 & 0.26 & 4 & 0.0016 & 0.61 & 3.25 & 0.69 & 1 & 0.0004 & 1.00 & 1.00 & 0.00 \\
\hline Outer & 5 & 0.0117 & 0.60 & 1.20 & 0.17 & 0 & 0 & - & 0 & - & 0 & 0 & - & 0 & - \\
\hline Total & 50 & 0.0169 & 0.22 & 2.34 & 0.25 & 4 & 0.0014 & 0.61 & 3.25 & 0.69 & 1 & 0.0003 & 1.00 & 1.00 & 0.00 \\
\hline \multicolumn{16}{|l|}{2009} \\
\hline Inner & 16 & 0.0157 & 0.41 & 1.31 & 0.11 & 1 & 0.0010 & 1.00 & 1.00 & 0.00 & 0 & 0 & - & 0 & - \\
\hline Outer & - & - & - & - & - & - & - & - & - & - & - & - & - & - & - \\
\hline Total & 16 & 0.0157 & 0.41 & 1.31 & 0.11 & 1 & 0.0010 & 1.00 & 1.00 & 0.00 & 0 & 0 & - & 0 & - \\
\hline \multicolumn{16}{|l|}{2010} \\
\hline Inner & 71 & 0.0289 & 0.20 & 2.72 & 0.25 & 1 & 0.0004 & 1.00 & 1.00 & 0.00 & 1 & 0.0004 & 0.99 & 4.00 & 0.00 \\
\hline Outer & 2 & 0.0053 & 0.96 & 1.00 & 0.00 & 0 & 0 & - & 0 & - & 0 & 0 & - & 0 & - \\
\hline Total & 73 & 0.0257 & 0.20 & 2.67 & 0.25 & 1 & 0.0004 & 1.00 & 1.00 & 0.00 & 1 & 0.0004 & 0.99 & 4.00 & 0.00 \\
\hline \multicolumn{16}{|l|}{2011} \\
\hline Inner & 6 & 0.0017 & 0.45 & 1.17 & 0.14 & 18 & 0.0051 & 0.27 & 1.44 & 0.14 & 41 & 0.0115 & 0.41 & 2.12 & 0.20 \\
\hline Outer & 1 & 0.0017 & 1.10 & 1.00 & 0.00 & 0 & 0 & - & 0 & - & 18 & 0.0300 & 0.74 & 3.67 & 0.31 \\
\hline Total & 7 & 0.0017 & 0.41 & 1.14 & 0.12 & 18 & 0.0043 & 0.27 & 1.44 & 0.14 & 59 & 0.0142 & 0.35 & 2.59 & 0.18 \\
\hline
\end{tabular}

Table 7.-Number of sightings ( $n$ ), estimated density (D, \#/km²), estimated abundance (N), coefficient of variation (CV), and $95 \%$ confidence interval (Cl) for bowhead, gray, and beluga whales by year and domain during BOWFEST aerial surveys from late August to mid-September.

\begin{tabular}{|c|c|c|c|c|c|c|c|c|c|c|c|c|c|c|c|}
\hline \multirow[b]{2}{*}{$\begin{array}{l}\text { Year and } \\
\text { Domain }\end{array}$} & \multicolumn{5}{|c|}{ Bowhead whale } & \multicolumn{5}{|c|}{ Gray whale } & \multicolumn{5}{|c|}{ Beluga whale } \\
\hline & $n$ & $\mathrm{D}$ & $\mathrm{N}$ & $\mathrm{CV}$ & $\mathrm{Cl}$ & $n$ & $\mathrm{D}$ & $\mathrm{N}$ & CV & $\mathrm{Cl}$ & $n$ & $\mathrm{D}$ & $\mathrm{N}$ & CV & $\mathrm{Cl}$ \\
\hline \multicolumn{16}{|l|}{2007} \\
\hline Inner & 5 & 0.0035 & 25 & 0.82 & $6-106$ & 9 & 0.0022 & 16 & 0.45 & $7-37$ & 5 & 0.0029 & 21 & 0.76 & 5-83 \\
\hline Outer & 0 & 0 & 0 & 0 & $0-0$ & 0 & 0 & 0 & 0 & $0-0$ & 4 & 0.0231 & 280 & 0.90 & $43-1,832$ \\
\hline Total & 5 & 0.0013 & 25 & 0.82 & $6-106$ & 9 & 0.0008 & 16 & 0.45 & $7-37$ & 9 & 0.0155 & 302 & 0.84 & $51-1,778$ \\
\hline \multicolumn{16}{|l|}{2008} \\
\hline Inner & 45 & 0.0138 & 100 & 0.35 & $51-196$ & 4 & 0.0011 & 8 & 0.69 & $2-28$ & 1 & 0.0003 & 2 & 1.00 & $0-12$ \\
\hline Outer & 5 & 0.0062 & 75 & 0.70 & $19-299$ & 0 & 0 & 0 & 0 & $0-0$ & 0 & 0 & 0 & 0 & $0-0$ \\
\hline Total & 50 & 0.0090 & 176 & 0.36 & $85-364$ & 4 & 0.0004 & 8 & 0.69 & $2-28$ & 1 & 0.0001 & 2 & 1.00 & $0-12$ \\
\hline \multicolumn{16}{|l|}{2009} \\
\hline Inner & 16 & 0.0083 & 60 & 0.36 & $30-123$ & 1 & 0.0005 & 4 & 1.01 & $1-20$ & 0 & 0 & 0 & 0 & $0-0$ \\
\hline Outer & - & - & - & & - & - & - & & - & - & - & & & & \\
\hline Total & 16 & 0.0083 & 60 & 0.36 & $30-123$ & 1 & 0.0005 & 4 & 1.01 & $1-20$ & 0 & 0 & 0 & 0 & $0-0$ \\
\hline \multicolumn{16}{|l|}{2010} \\
\hline Inner & 71 & 0.0255 & 185 & 0.30 & 103-335 & 1 & 0.0002 & 1 & 1.01 & $0-8$ & 1 & 0.0011 & 8 & 0.99 & $2-43$ \\
\hline Outer & 2 & 0.0023 & 27 & 0.97 & 3-218 & 0 & 0 & 0 & 0 & $0-0$ & 0 & 0 & 0 & 0 & $0-0$ \\
\hline Total & 73 & 0.0110 & 213 & 0.30 & $120-379$ & 1 & 0.00008 & 1 & 1.01 & $0-8$ & 1 & 0.0004 & 8 & 0.99 & $2-43$ \\
\hline \multicolumn{16}{|l|}{2011} \\
\hline Inner & 6 & 0.0011 & 8 & 0.55 & 3-22 & 18 & 0.0025 & 18 & 0.28 & $10-31$ & 41 & 0.0169 & 123 & 0.43 & $54-280$ \\
\hline Outer & 1 & 0.0012 & 14 & 1.18 & $2-131$ & 0 & 0 & 0 & 0 & $0-0$ & 18 & 0.0679 & 825 & 0.75 & $150-4,530$ \\
\hline Total & 7 & 0.0011 & 22 & 0.80 & $4-111$ & 18 & 0.0009 & 18 & 0.28 & $10-31$ & 59 & 0.0112 & 948 & 0.66 & $208-4,320$ \\
\hline
\end{tabular}



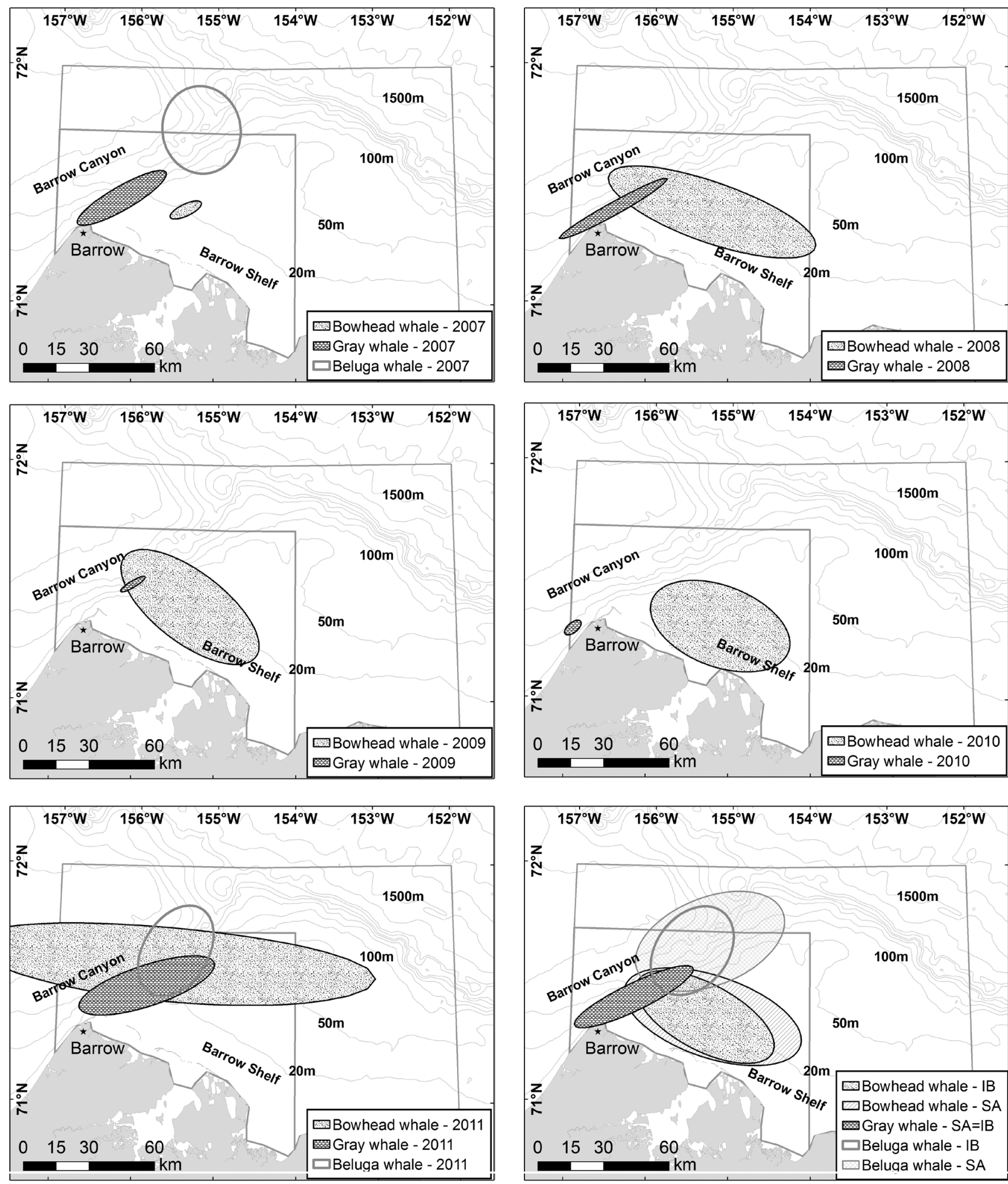

Figure 8.- Standard deviation ellipses (capturing approximately $68 \%$ of sightings weighted by group size) showing the regions occupied by bowhead, gray, and beluga whales during BOWFEST aerial surveys from late August to mid-September during the period 2007-11. Beluga sample sizes were too small during the period 2008-2010 to create ellipses. Given increased effort in the inner box (IB), the same analyses were run using only sightings within this region to confirm inner box distributions were not significantly different from sightings in the entire study area (SA) for all years combined (last panel). 
Table 8.-Logistic regression and ROC model results: final model parameters; AIC scores; AUC and threshold values; habitat preference areas; and the proportion of habitat in the inner box (IB) of the BOWFEST study area for bowhead, gray, and beluga whales.

\begin{tabular}{|c|c|c|c|c|c|c|c|}
\hline Whale type & Model parameters & $\mathrm{k}$ & AlC & AUC & Threshold & Habitat area $\left(\mathrm{km}^{2}\right)$ & Percent of IB \\
\hline Bowhead & DISTSHORE + DISTSHELF & 2 & 532.39 & 0.67 & 0.51 & 2575.81 & 37.96 \\
\hline Gray & BATHY+SLOPE+DISTSHORE+DISTSHELF & 4 & 137.81 & 0.96 & 0.61 & 801.64 & 11.81 \\
\hline Beluga & BATHY & 1 & 107.14 & 0.82 & 0.40 & 1947.94 & 28.71 \\
\hline
\end{tabular}

Table 9.-Bowhead whales observed traveling within the BOWFEST aerial survey study area from late August to mid-September during the period 2007-11. (Note: sample size was too small in 2007).

\begin{tabular}{|c|c|c|c|c|c|}
\hline Year & Sightings headed westerly $\left(226^{\circ}-315^{\circ}\right)$ & Total "travel" sightings with headings & Percent heading westerly & Rayleigh's uniformity test (KCS, 2012) & Grand mean vector \\
\hline 2007 & & 2 & - & & \\
\hline 2008 & 12 & 21 & $57.1 \%$ & $Z=7.103, p=4.82 \mathrm{E}-4$ & $294.774^{\circ}$ \\
\hline 2009 & 4 & 8 & $50.0 \%$ & $Z=1.672, p=0.192$ & \\
\hline 2010 & 16 & 52 & $30.8 \%$ & $Z=0.414, p=0.661$ & \\
\hline 2011 & 6 & 12 & $50.0 \%$ & $Z=1.130, p=0.33$ & \\
\hline Total & 38 & 93 & $40.9 \%$ & & \\
\hline
\end{tabular}
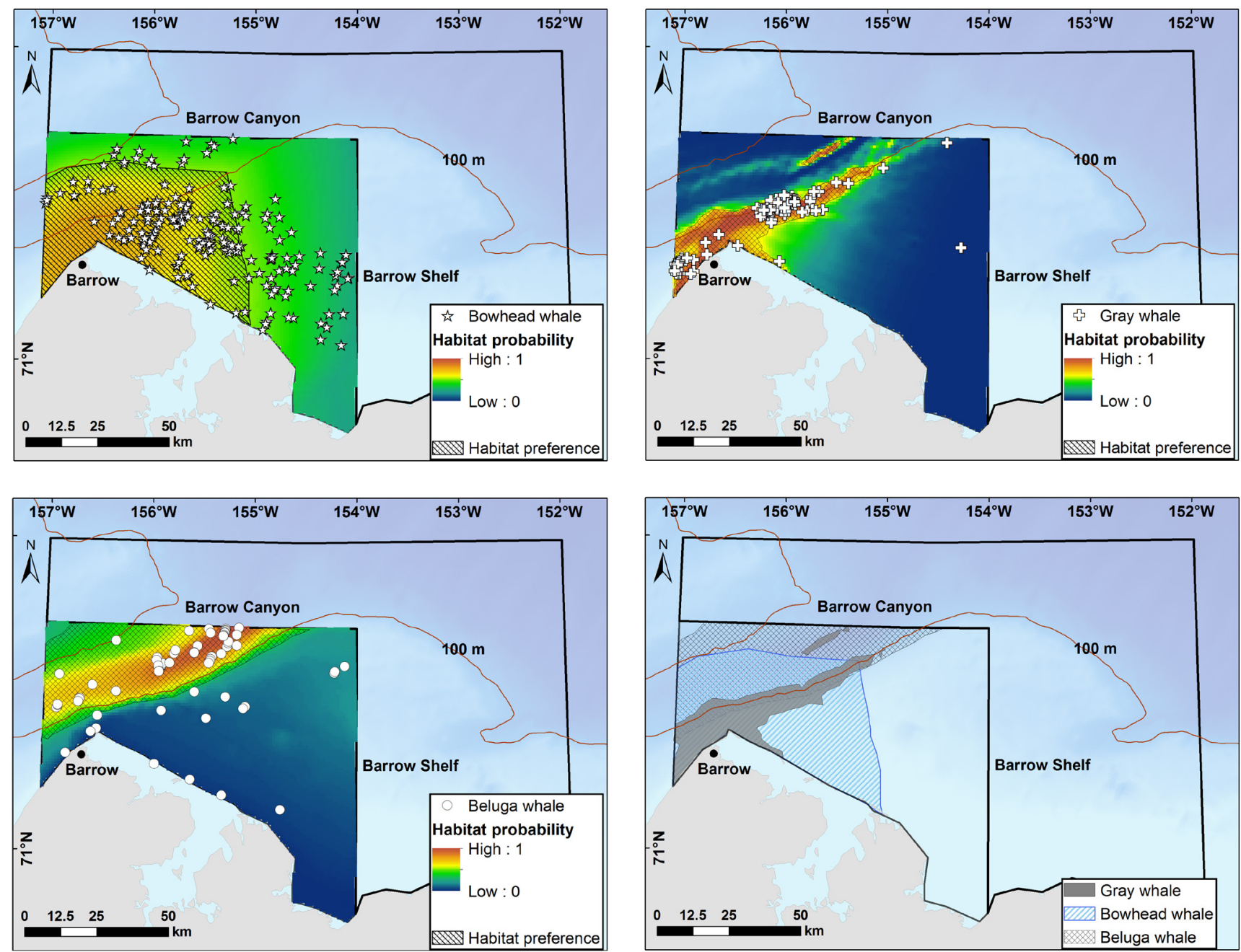

Figure 9.- Late summer habitat probability (low/blue to high/red) and preference (black cross-hatch) for bowhead (stars), gray (crosses), and beluga (circles) whales near Barrow, Alaska, based on sightings within the inner box of the BOWFEST study area collected during late August to mid-September during the period 2007-11. Habitat preferences for all three species are shown in the last panel. 

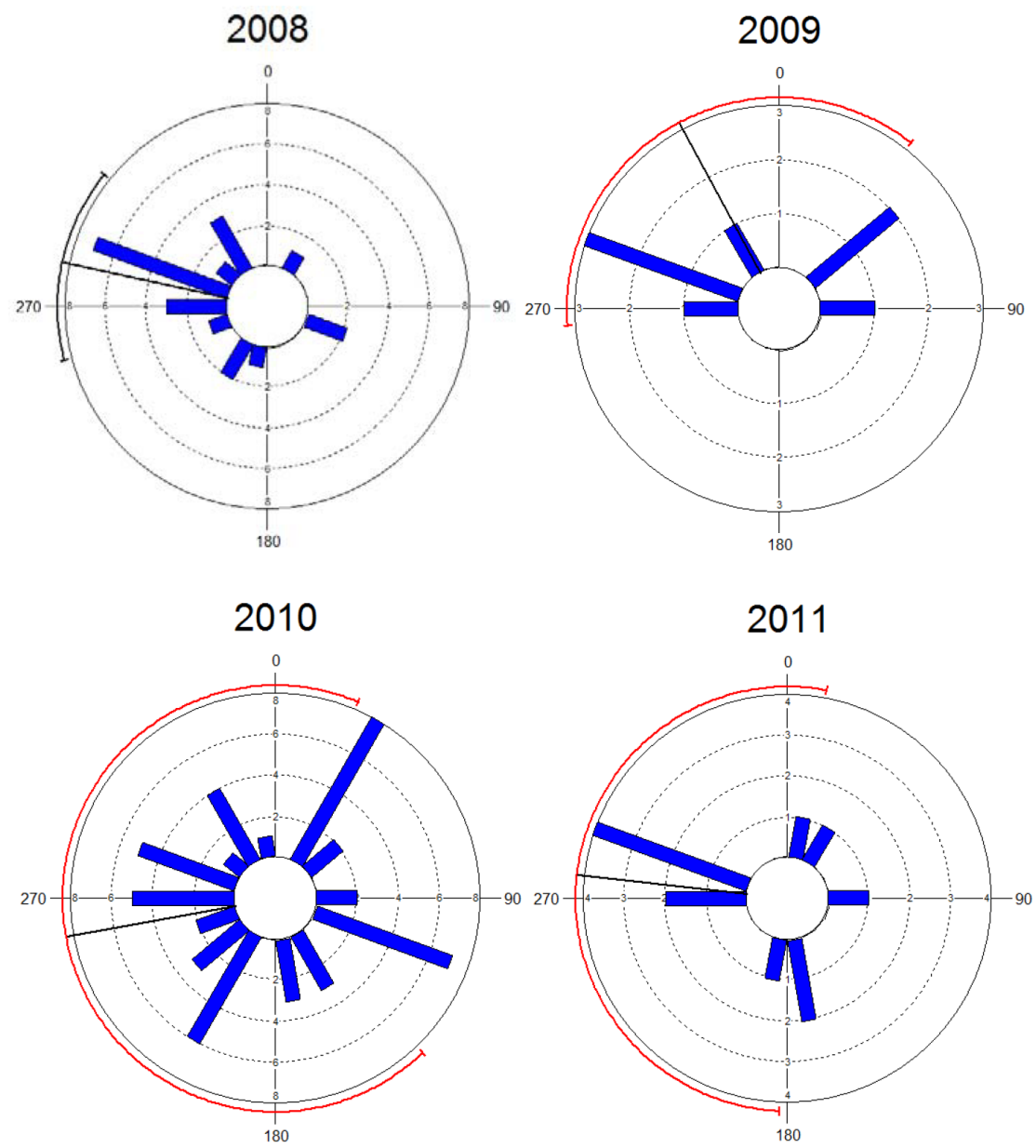

Figure 10.- Swim directions of bowhead whales observed during BOWFEST aerial surveys from late August to mid-September during the period 2008-11 (Note: sample size was too small in 2007). Only 2008 showed a significant clustering of sightings in any direction (black line as opposed to red lines in other years).

During the aerial survey in 2010, groups of bowhead whales were observed with open mouths swimming in echelon formation, and in an unusual position on their sides instead of upright (Fish et al., 2013). Echelon formation had been documented before for bowhead whales, but usually whales were upright (Würsig and Clark, 1993; George et al. ${ }^{6}$ ), though a lone whale skim feeding on its side was photographed in 2006 in the BOWFEST study area (Moore et al. 2010a). Moore et al. (2010a) also described "head lunging" bowhead whales observed on two occasions in 2006, a behavior not observed during in 2009 remained along the $20 \mathrm{~m}$ isobath, while the whales photographed five days later in 2011 had separated, but both remained in deeper waters $(>100 \mathrm{~m})$, one in Barrow Canyon and the other at the easternmost border of the study area (Fig. 14). The individual that remained in Barrow Canyon was the only intrayear-matched whale that appeared to have been feeding (fecal plume evident in the photograph taken on $9 / 9 / 2011$ ).

There were three resightings of bowhead whales among the 5 years of BOWFEST photographs (Fig. 14). These interyear sightings included one whale photographed in 2007 and 2009, one in 2007 and 2011, and one in 2008 and 2010. Two of these whales were resighted along the $20 \mathrm{~m}$ isobath, near their initial sighting location two years earlier (Fig. 14). The third whale was first observed near the $20 \mathrm{~m}$ isobath but 5 years later was photographed in deep water $(>100 \mathrm{~m})$ on the easternmost boundary of the study area (Fig. 14). Both whales observed in 2007 appeared to be feeding (mud on rostrums), but only the whale resighted in 2009 had evidence of feeding (mud on the rostrum). Mud was also on the rostrum of the whale observed again in 2010 , but there was no evidence of feeding in the 2008 image.

In 2011, the bowhead aerial abundance spring survey (BAASS) flew in the Barrow area photographing whales from April to June (Mocklin et al. ${ }^{13}$ ). While analyses still continue on this dataset, a match between this dataset and BOWFEST included one bowhead whale mother with calf photographed in May and September (Fig. 14 and 15). Both sightings occurred over deep water $(>100 \mathrm{~m})$; at the easternmost border of the study area in the spring and in Barrow Canyon in late summer (Fig. 14). The mother had mud on her chin and tip of her rostrum in the photograph taken during the spring mi-

${ }^{13}$ Mocklin, J., J. C. George, M. Ferguson, L. Vate Brattström, V. Beaver, B. Rone, C. Christman, A. Brower, B. Shea, C. Accardo. 2012. Aerial photography of bowhead whales near Barrow, Alaska, during the 2011 spring migration. Pap. SC/64/BRG3 pres. to IWC Sci. Committee, May 2012, 9 p. 
gration (possible evidence of feeding behavior) (Fig. 15A).

\section{Age Classes}

Using photogrammetric lengths, bowhead whales were sorted into specific age classes: calf, juvenile, and adult (Fig. 16). Of the 654 images of sufficient quality to obtain length measurements (prior to matching), 65\% were juveniles (between 6 and $13 \mathrm{~m}$ ), $35 \%$ were adults $(>13 \mathrm{~m})$, and $1 \%$ were calves $(<6 \mathrm{~m})$. While there was no statistical difference between percentages of juveniles and adults during the study period (paired $t$-test; $p=0.15$ ), three of the 5 years $(2008,2010,2011)$ included large numbers of younger juveniles in the photographic sample. Rugh (1990) noted that because young whales have fewer scars, which accumulate as bowheads age, these whales may go unrecognized, and therefore, unmatched. Of 213 images classified as juveniles and assigned a unique whale number, only $6(3 \%)$ were highly marked and $12(6 \%)$ were moderately marked in at least one zone on the body. This likely contributed to the low number of photographic resightings during the BOWFEST study period.

Obtaining adequate lengths for feeding whales proved to be difficult. Image quality ratings for 276 feeding whales (including within day, intrayear, and interyear matches) were a 3 (i.e., not useful) for all zones of the body for $157(58 \%)$ of these images. Lengths were obtained for about 34\% of whales identified as feeding (Table $10)$. Of these, $46 \%$ were juveniles and $54 \%$ were adults.

\section{Conclusions}

The aerial survey component of BOWFEST was designed to docu-
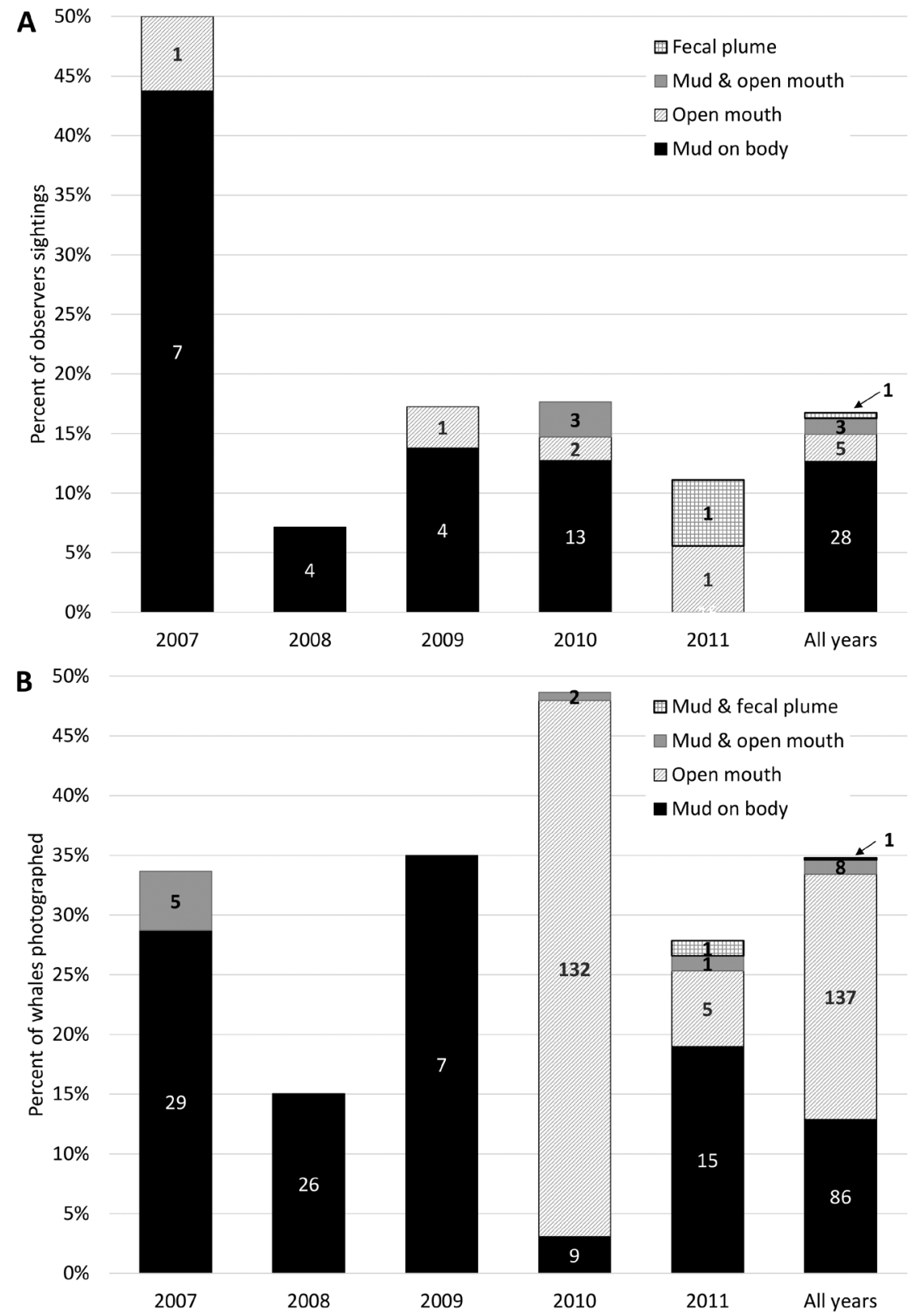

Figure 11.-Percentage of bowhead whales (A) observed and (B) photographed displaying feeding behaviors during BOWFEST aerial surveys from late August to mid-September for the period 2007-11. Sample sizes are noted within each column.

Table 10.-Bowhead whales observed feeding within the BOWFEST aerial survey study area from late August to mid-September during the period 2007-11. Lengths (when available) were binned in meter increments.

\begin{tabular}{|c|c|c|c|c|c|c|c|c|c|c|c|c|}
\hline \multirow[b]{2}{*}{ Year } & \multicolumn{6}{|c|}{ Juveniles $(6-<13 m)$} & \multicolumn{5}{|c|}{ Adults (>13m) } & \multirow[b]{2}{*}{ No length } \\
\hline & $7-<8$ & $8-<9$ & $9-<10$ & $10-<11$ & $11-<12$ & $12-<13$ & $13-<14$ & $14-<15$ & $15-<16$ & $16-<17$ & $17-<18$ & \\
\hline 2007 & & & & & 2 & & 6 & 13 & & 3 & 2 & 8 \\
\hline 2008 & & 1 & 2 & 4 & 4 & 1 & 3 & 3 & 1 & & & 7 \\
\hline 2009 & & & & & & & & 1 & & & & 6 \\
\hline 2010 & 1 & 1 & 2 & 1 & 5 & & & & & & & 133 \\
\hline 2011 & & & 1 & 2 & 4 & 5 & 7 & 1 & 2 & & & \\
\hline Total & 1 & 2 & 5 & 7 & 15 & 6 & 16 & 18 & 3 & 3 & 2 & 154 \\
\hline
\end{tabular}



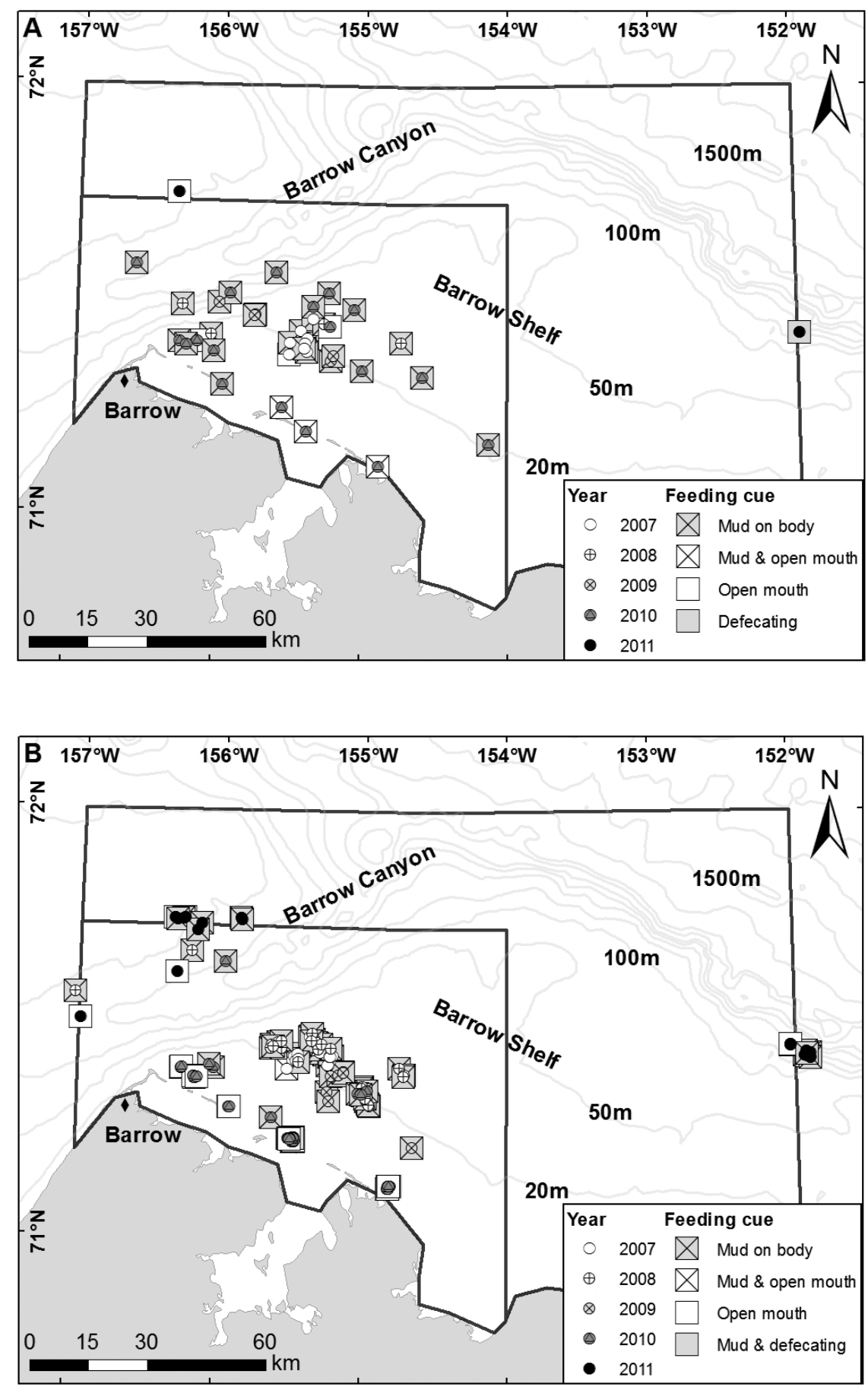

Figure 12.-Locations of feeding bowhead whales (A) observed and (B) photographed during BOWFEST aerial surveys from late August to mid-September for the period 2007-11. ment patterns and variability in the timing and distribution of bowhead whales and to provide an estimate of temporal and spatial habitat use near Barrow, Alaska. Abundance estimates during this time period ranged from 22 ( $C V 0.80)$ to 213 ( $C V 0.30$ ) bowhead whales within the combined study areas. Traveling was the most commonly recorded behavior, but swim direction was highly variable among years, suggesting bowhead whales were not migrating through the area during the survey period. Only in 2008 was swim direction significantly clustered around a mean and clearly westward. This also coincided with the lowest percentage of whales photographed feeding during the study period, and the only year when skim feeding was not observed or photographed.

Most bowhead whales were located in shelf waters $<30$ m deep when feeding behaviors were observed $(81 \%)$ or photographed $(90 \%)$. Habitat partitioning was evident among the cetacean species observed in greatest numbers: bowhead, gray, and beluga whales. Bowhead distribution aligned close to shore, extending from within Barrow Canyon on the western boundary of the study area toward the eastern edge, running along the $20 \mathrm{~m}$ isobath in almost all years. Gray whales aligned along the shelf break near Barrow in all years, while belugas, when present, were primarily offshore over submarine canyon waters. This patterning among species was consistent with partitioning observed on a much larger scale across the Beaufort and Chukchi seas (e.g., Clarke et al., 2016). When modeling habitat preferences based on all survey years, four parameters were considered: bathymetry, bathymetric slope, distance from shore, and distance from the shelf break. Both distance from shore and distance from the shelf break were significant in predicting the presence of bowhead whales. All four parameters were significant in predicting gray whale presence. Only bathymetry was significant in predicting beluga whale presence.

Although the paucity of individual 
bowhead whale resightings between survey days suggested very low residence times, we found the photogrammetric sample was largely comprised of juveniles. Young whales typically are unmarked and, therefore, not matched. Only one instance of feeding was documented among the intrayear matches ( 6 images total) though the whales remained within the BOWFEST study area. The across season match of a mother with calf had evidence of feeding during the spring but not late summer. Among the interyear matches, 4 of the 6 images documented feeding behaviors for each whale that was re-identified.

It appears that some whales return to the region after initially heading west into the Chukchi Sea during what would be considered the migratory period. Quakenbush et al. (2010) performed a kernel density analysis of tagged whale movements that showed, in September, the area with the highest probability of use was northeast of Barrow. Their satellite tag data also showed that bowhead whales do not move across the Beaufort Sea in a continuous stream. Three of the 19 tagged whales left the Barrow area heading west, only to return and spend 13-32 days in the waters off Barrow (Quakenbush et al., 2010). All of our intrayear matched whales moved east of their original sighting location, which was not expected so close to the westbound fall migration.

Aggregations of bowhead whales have been linked to wind speeds and directions that in association with shelf and coastal currents, retain and concentrate their prey on the shelf near Barrow (Ashjian et al., 2010; Okkonen et al., 2011). Although, bowheads were most abundant in the BOWFEST survey area in 2008 and 2010, this did not necessarily mean that whales were feeding. Further analysis of the BOWFEST dataset, in particular the whales displaying feeding behaviors, may provide additional insights.

As the bowhead population continues to grow and "there is no evidence that the population size is above the maximum net productivity level or

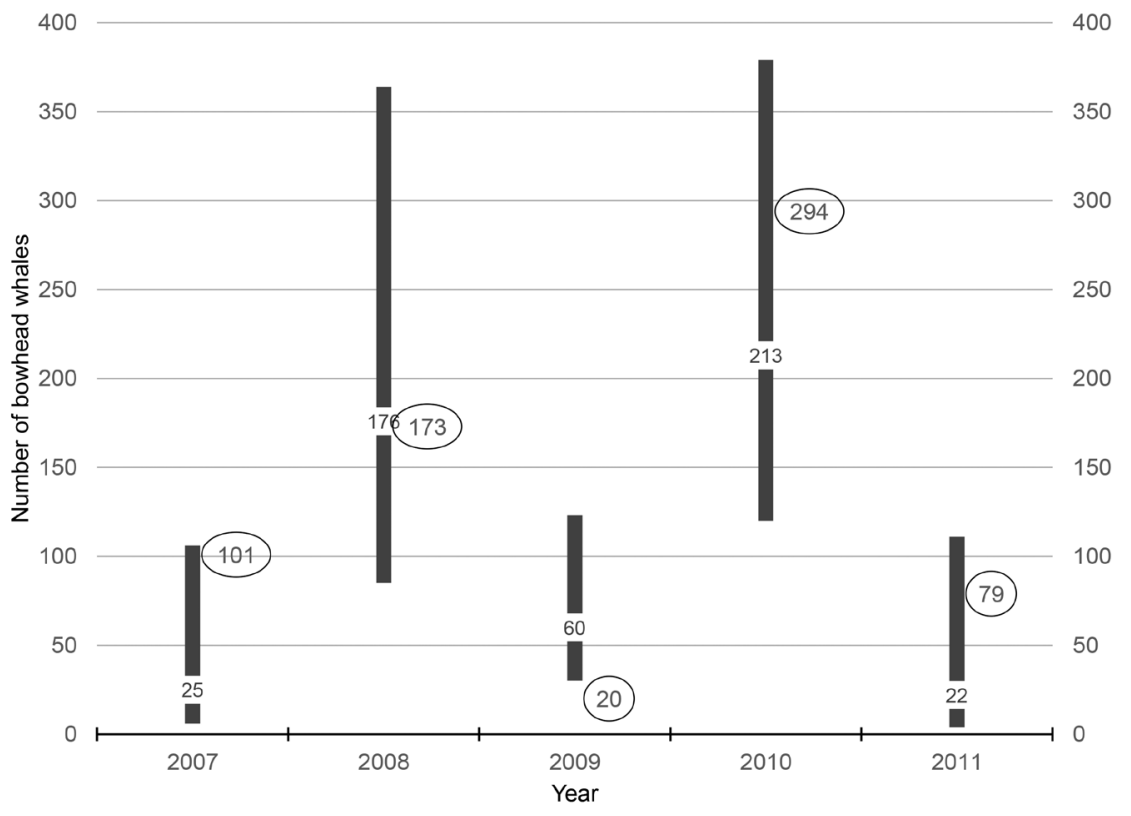

Figure 13.-Annual abundance estimates with associated confidence intervals (black bars) and number of unique bowhead whales photographed (ovals) during BOWFEST aerial surveys from late August to mid-September for the period 2007-11.

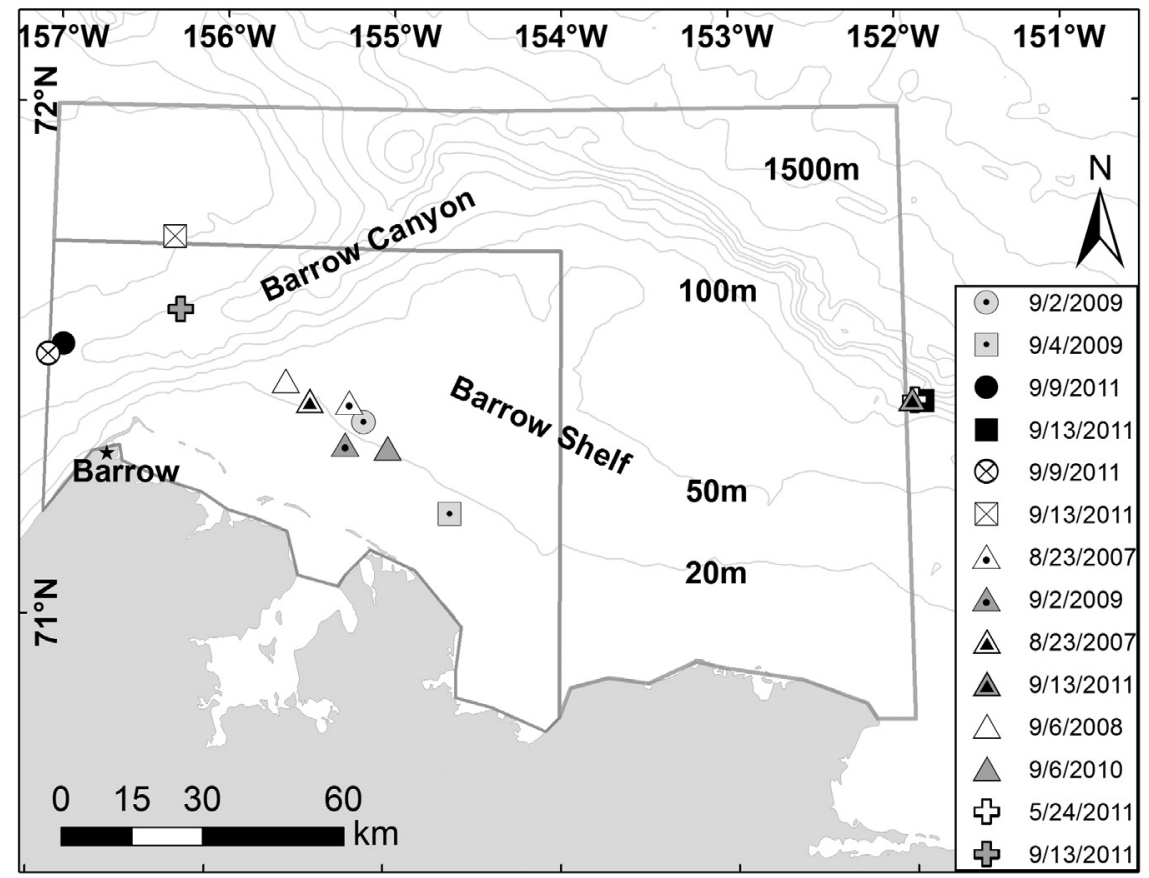

Figure 14.- Locations of bowhead whales with photographic matches. There were three intrayear BOWFEST matches (circle: first sighting; square subsequent), three interyear BOWFEST matches (triangles), and one intrayear match between spring (BAASS survey) to late summer (BOWFEST) (crosses). 


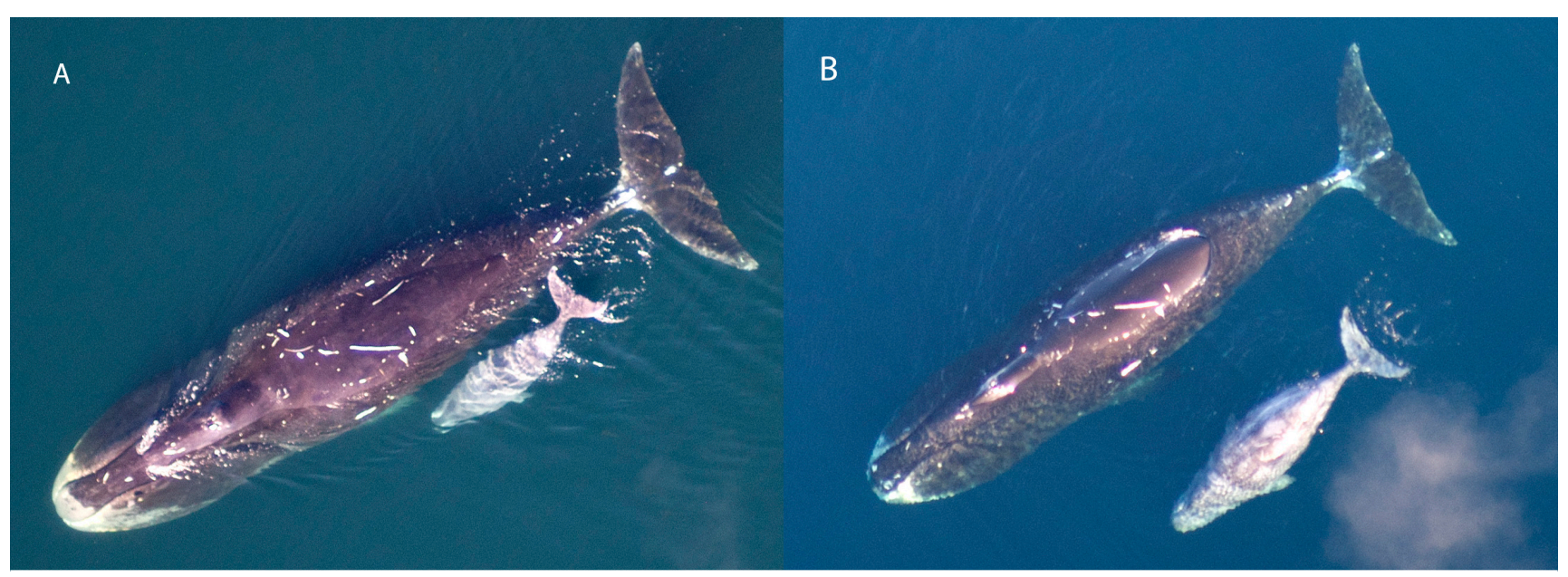

Figure 15.- Intrayear matches of a bowhead whale mother with calf observed (A) during the BAASS aerial survey April-June 2011 and (B) BOWFEST aerial surveys late August to mid-September 2011. Note the change in calf size relative to the adult. The mother had mud on her chin and tip of her rostrum in the spring photograph, possibly indicating feeding behavior.

near carrying capacity" (Givens et al. $\left.{ }^{14}\right)$, more whales may seek foraging opportunities in the western Beaufort and the Chukchi seas in response to increased feeding pressure in the eastern Beaufort Sea foraging areas. Other species have extended their ranges or are showing up in greater numbers in the Chukchi and western Beaufort seas - such as gray whales, humpback whales, fin whales, Balaenoptera physalus; minke whales, $B$. acutorostrata; and killer whales (e.g., Clarke et al., 2013). This suggests the potential for increasing prey competition among zooplankton feeders, as well as increased predation by killer whales.

Industrial activity is also expected to increase in the Arctic (Reeves et al., 2012). Although bowhead whales are exposed to oil and gas development activities in the eastern Beaufort Sea and expanding activities (i.e., seismic exploration) in the Chukchi and western Beaufort seas (e.g., Moore et al., 2012), commercial fishing and most shipping operations have not yet

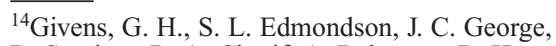
R. Suydam, R. A. Charif, A. Rahaman, D. Hawthorne, B. Tudor, R. A. DeLong, and C. W. Clark. 2013. Estimate of 2011 abundance of the Bering-Chukchi-Beaufort Seas bowhead whale population. Pap. SC/65a/BRG1 pres. to IWC Sci. Committee, May 2013, 30 p.

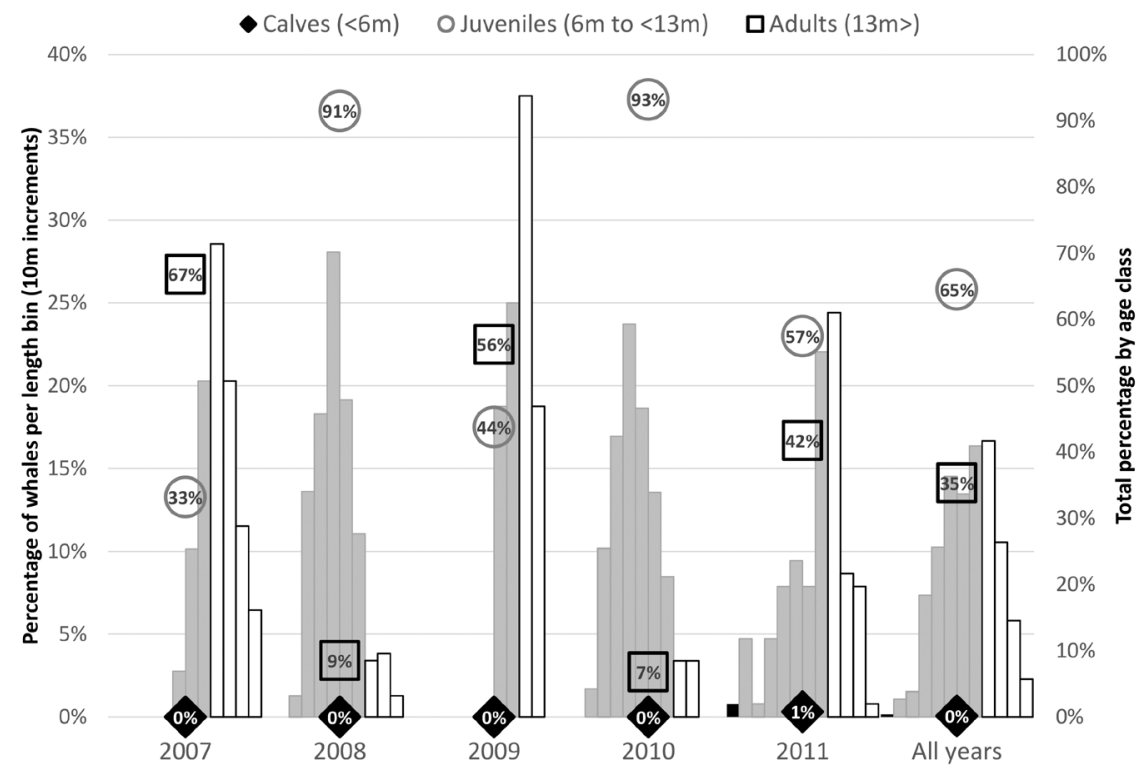

Figure 16.-Age class distribution of bowhead whales during BOWFEST aerial surveys from late August to mid-September for the period 2007-11. Histogram shows percentage of whales per length bin in $10 \mathrm{~m}$ increments for calves (black columns), juveniles (gray columns), and adults (white columns). Total percentage by age class is shown within each symbol for calves (diamonds), juveniles (circles), and adults (squares).

reached these regions. These activities will not only affect bowhead whales and other species endemic to the Arctic (Reeves et al., 2014), but potentially species expanding their range into this region. Mitigating the potential impacts on these species from these activities will require putting preemptive measures in place (Moore et al., 2012; Reeves et al., 2012, 2014). The BOWFEST aerial study provides a 5-year record of late summer presence of cetaceans in the western Beaufort Sea, adding to the growing body of 
knowledge of these species and their habitat preferences in a region undergoing rapid change.

\section{Acknowledgments}

Minerals Management Service (now the Bureau of Ocean Energy Management) funded the BOWFEST program through an Interagency Agreement between BOEM and NMML (M08PG 20021), as part of the BOEM Alaska Environmental Studies Program. Charles Monnett (BOEM) provided guidance, support, and inspiration as project coordinator from 2007-2011. Jeffrey Denton (BOEM) saw BOWFEST through to its conclusion in 2012.

NOAA's Aircraft Operation Center provided the aircraft and crew. Our pilots were Jason Mansour, Wally Pierce, and Nicole Cabana in 2007; Nicholas Toth and Jon French in 2008; Nicholas Toth and Chris Daniels in 2009; Brad Fritzler and Rob Mitchell in 2010; and Brad Fritzler and Francisco Fuenmayor in 2011. These pilots filled a critical role in keeping the aircraft at the preferred altitude while flying intricate patterns over moving whales. Ron Pauley, Mike Merek, and Rob Militic provided mechanical support for the aircraft through these years. Dee Allen flew with us one day in 2009 (assisting with video photography) and Christy Sims joined the team in 2011.

Wayne Perryman loaned us a radar altimeter and provided technical advice, and Don LeRoi loaned us the FMC mount and assisted with the camera mount installation. Craig George provided the land calibration target. Noah Lawrence-Slavas assisted with the design of the water-borne target used in 2008-09, and Frederick Brower and Catherine Berchok towed this floating target array within the survey area. Janet Clarke provided the statistics and figure for the bowhead swim direction analysis and Rayleigh test. Alex Zerbini consulted on the distance sampling analysis. This study was conducted under MMPA Scientific Research Permit No. 782-1719 (years 2007-10) and Permit No. 14245 (2011).

\section{Literature Cited}

Ashiian, C. J., S. R. Braund, R. G. Campbell, J. C. George, J. Kruse, W. Maslowski, S. E. Moore, C. R. Nicolson, S. R. Okkonen, B. F. Sherr, E. B. Sherr, and Y. H. Spitz. 2010. Climate variability, oceanography, bowhead whale distribution, and Iñupiat subsistence whaling near Barrow, Alaska. Arctic 63:179-194.

Braham, H. W., and M. E. Dahlheim. 1982. Killer whales in Alaska documented in the Platforms of Opportunity Program. Rep. Int. Whal. Comm. 32:643-646.

Braham, H., B. Krogman, S. Leatherwood, W. Marquette, D. Rugh, M. Tillman, J. Johnson, and G. Carroll. 1979. Preliminary report of the 1978 spring bowhead whale research program results. Rep. Int. Whal. Comm. 29:291-306.

Buckland, S. T., D. R. Anderson, K. P. Burnham, and J. L. Laake. 1993. Distance sampling: estimating abundance of biological populations. Chapman and Hall, Lond., 446 p.

, D. L. Borchers, and L. Thomas. (Editors). 2001. Introduction to distance sampling: estimating abundance of biological populations. Oxford Univ. Press, N.Y., 448 p.

$\overrightarrow{\text { (Editors). } 200}, \overline{4 \text {. Advanced distance sampling: }}$ : estimating abundance of biological populations. Oxford Univ. Press, N.Y., 434 p.

Burnham, K. P., and D. R. Anderson. 2002. Model selection and multi-model inference: A practical information theoretic approach. Springer, N.Y., 2nd ed., 488 p.

Carroll, G. M., J. C. George, L. F. Lowry, and K. O. Coyle. 1987. Bowhead whale (Balaena mysticetus) feeding near Point Barrow, Alas$\mathrm{ka}$, during the 1985 spring migration. Arctic 40:105-110. (doi: https://doi.org/10.14430/ $\operatorname{arctic1754)}$

Citta, J. J., L. T. Quakenbush, S. R. Okkonen, M. L. Druckenmiller, W. Maslowski, J. Clement-Kinney, J. C. George, H. Brower, R. J. Small, C. J. Ashjian, L. A. Harwood, and M. P. Heide-Jørgensen. 2015. Ecological characteristics of core-use areas used by BeringChukchi-Beaufort (BCB) bowhead whales, 2006-2012. Prog. Oceanogr. (136):201222. (doi: https://doi.org/10.1016/j. pocean.2014.08.012).

Clarke, J. T., A. S. Kennedy, and M. F. Ferguson. 2016. Bowhead and gray whale distributions, sighting rates, and habitat associations in the eastern Chukchi Sea, summer and fall 2009-15, with a retrospective comparison to 1982-91. Arctic 69(4):359-377. (doi: https:// doi.org/10.14430/arctic4597).

S. E. Moore, and M. M. Johnson. 1993. Observations on beluga fall migration in the Alaskan Beaufort Sea and northeastern Chukchi Sea, 1982-91. Rep. Int. Whal. Comm. 43:387-396.

K. Stafford S. E. Moore, B. Rone, L. Aerts, and J. Crance. 2013. Subarctic cetaceans in the southern Chukchi Sea: Evidence of recovery or response to a changing ecosystem. Oceanography 26(4):136-149. (doi: https://doi.org/10.5670/oceanog.2013.81).

Fish, F. E., K. T. Goetz, D. J. Rugh, and L. V. Brattström. 2013. Hydrodynamic patterns associated with echelon formation swimming by feeding bowhead whales (Balaena mysticetus). Mar. Mammal Sci. 29(4):E498-E507.
IWC. 2010. Report of the Scientific Committee Int. Whaling Comm., IWC/62/Rep 1, 91 p.

Jakobsson, M., L. A. B. Mayer, J. A. Coakley,S. Dowdeswell, B. Forbes, H. Fridman, R.Hodnesdal, R. Noormets, M. Pedersen, H. W. Rebesco, Y. Schenke, D. Zarayskaya, A. Accettella, R. M. Armstrong, P. Anderson, A. Bienhoff, C. Camerlenghi, I. Church, M. Edwards, J. V. Gardner, J. K. Hall, B. Hell, O. B. Hestvik, Y. Kristoffersen, R.Marcussen, D. Mohammad, S. V. Mosher, M. T. Nghiem, P. G. Pedrosa, P. Travaglini, and P. Weatherall. 2012. The International bathymetric chart of the Arctic Ocean (IBCAO) Version 3.0. Geophysical Res. Letters. (doi: https://doi. org/10.1029/2012GL052219).

KCS. 2012. Oriana Version 4.01. Kovach Computing Services. Anglesey, Wales (http:// www.kovcomp.com)

Koski, W. R., R. A. Davis, G. W. Miller, and D. E. Withrow. 1992. Growth rates of bowhead whales as determined from low-level aeria photogrammetry. Rep. Int. Whal. Comm. 42:491-499.

D. J. Rugh, A. E. Punt, and J. Zeh 2006. An approach to minimize bias in estimation of the length-frequency distribution of bowhead whales (Balaena mysticetus) from aerial photogrammetric data. J. Cetacean Res. Manag. 8:45-54.

Laake, J., D. Borchers, L. Thomas, and D. Miller. 2007. Mark-recapture distance sampling (mrds). R package version 1.3.1.

Landino, S. W., S. D. Treacy, S. A. Zerwick, and J. B. Dunlap. 1994. A large aggregation of bowhead whales (Balaena mysticetus) feeding near Point Barrow, Alaska, in late October 1992. Arctic 47(3):232-235. (doi: https:// doi.org/10.14430/arctic1293).

Ljungblad, D. K., S. E. Moore, and J. T. Clarke. 1986. Assessment of bowhead whale (Balaena mysticetus) feeding patterns in the Alaskan Beaufort and northern Chukchi seas via aerial surveys, fall 1979-84. Rep. Int. Whal. Comm. 36:265-272.

Mocklin J., D. J. Rugh, W. R. Koski, and N. Lawrence-Slavas. 2010. Comparison of land-based vs. floating calibration targets used in aerial photogrammetric measurements of whale lengths. Mar. Mammal Sci. 26:969-976.

D. Rugh, S. Moore, and R. Angliss. 2012. Using aerial photography to investigate evidence of feeding by bowhead whales. Mar. Mammal Sci. 28(3):602-619.

Moore, S. E. 1992. Summer records of bowhead whales in the northeastern Chukchi Sea. Arctic 45:398-400. (doi: https://doi. org/10.14430/arctic1419).

2000. Variability of cetacean distribution and habitat selection in the Alaskan Arctic, autumn 1982-91. Arctic 53:448-460. (doi: https://doi.org/10.14430/arctic874). and J. T. Clarke. 1992. Patterns of bowhead whale distribution and abundance near Barrow, Alaska, in fall 1982-1989. Mar. Mammal Sci. 8(1):27-36. and R. R. Reeves. 1993. Distribution and movement. In J. J. Burns, J. J. Montague, and C.J. Cowles (Editors), The bowhead whale, p. 313-386. Spec. Publ. 2, Soc. Mar. Mammal., Lawrence, Kan., 787 p. and D. P. DeMaster. 1998 Cetacean habitats in the Alaskan Arctic. J. Northw. Atl Fish. Sci. 22:55-69.

J. C. Bennett, and D. K. Ljung- 
blad. 1989. Use of passive acoustics in conjunction with aerial surveys to monitor the fall bowhead whale (Balaena mysticetus) migration. Rep. Int. Whal. Comm. 39:291-295. D. P. DeMaster, and P. K. Dayton.

2000. Cetacean habitat selection in the Alaskan Arctic during summer and autumn. Arctic 53:432-447. (doi: https://doi.org/10.14430/ $\operatorname{arctic} 873)$.

J. C. George, G. Sheffield, J. Bacon, and C. Ashjian. 2010a. Bowhead whale distribution and feeding near Barrow, Alaska in late summer 2005-06. Arctic 63:195-205. (doi: https://doi.org/10.14430/arctic974).

K. M. Stafford, and L. M. Munger.

2010b. Acoustic and visual surveys for bowhead whales in the western Beaufort and far northeastern Chukchi seas. Deep-Sea Res. II 57:153-157.

R. R. Reeves, B. L. Southall, T. J.

Ragen, R. S. Suydam, and C. W. Clark. 2012. A new framework for assessing the effects of anthropogenic sound on marine mammals in a rapidly changing Arctic. BioScience 62(3):289-295 (doi: https://doi.org/10.1525/ bio.2012.62.3.10).

Muto, M. M., V. T. Helker, R. P. Angliss, B. A. Allen, P. L. Boveng, J. M. Breiwick, M. F. Cameron, P. J. Clapham, S. P. Dahle, M. E. Dahlheim, B. S. Fadely, M. C. Ferguson, L. W. Fritz, R. C. Hobbs, Y. V. Ivashchenko, A. S. Kennedy, J. M. London, S. A. Mizroch, R. R. Ream, E. L. Richmond, K. E. W. Shel- den, R. G. Towell, P. R. Wade, J. M. Waite, and A. N. Zerbini. 2016. Alaska marine mammal stock assessments, 2015. U.S. Dep. Commer., NOAA Tech. Memo. NMFS-AFSC-323, 300 p. (doi: https://doi.org/10.7289/ V5/TM-AFSC-323).

Okkonen, S. R., C. Ashjian, R. G. Campbell, J. T. Clarke, S. E. Moore, and K. D. Taylor. 2011. Satellite observations of circulation features associated with a bowhead whale feeding 'hotspot' near Barrow, Alaska. Remote Sens. Environ. 115:2,168-2,174. (doi: https://doi.org/10.1016/j.rse.2011.04.024).

Quakenbush, L. T., J. J. Citta, J. C. George, R. J. Small, and M. P. Heide-Jørgensen. 2010. Fall and winter movements of bowhead whales (Balaena mysticetus) in the Chukchi Sea and within a potential petroleum development area. Arctic 63:289-307. (doi: https://doi. org/10.14430/arctic1493).

R Development Core Team, 2008. R: a language and environment for statistical computing, Vienna, Austria ed. R Foundation for Statistical Computing, Vienna, Austria. ISBN 3-900051-07-0. URL: http://www.R-project. orgS.

Reeves, R., C. Rosa, J. C. George, G. Sheffield, and M. Moore. 2012. Implications of Arctic industrial growth and strategies to mitigate future vessel and fishing gear impacts on bowhead whales. Mar. Pol. 36:454-462. (doi: https://doi.org/10.1016/j. marpol.2011.08.005)
P. J. Ewins, S. Agbayani, M. P. Heide-Jørgensen, K. M. Kovacs, C. Lydersen, R. Suydam, W. Elliot, G. Polet, Y. van Dijk, and R. Blijleven. 2014. Distribution of endemic cetaceans in relation to hydrocarbon development and commercial shipping in a warming Arctic. Mar. Pol. 44:375-389. (doi: https://doi.org/10.1016/j. marpol.2013.10.005)

Rugh, D. J. 1990. Bowhead whales reidentified through aerial photography near Point Barrow, Alaska. Rep. Int. Whal. Comm. (SC/ A88/ID15) Spec. Iss. 12:289-294.

J. E. Zeh, W. R. Koski, L. S. Baraff, G. W. Miller, and K. E. W. Shelden. 1998. An improved system for scoring photo quality and whale identifiability in aerial photographs of bowhead whales. Rep. Int. Whal Comm. (SC/49/AS19) 48:501-512.

D. DeMaster, A. Rooney, J. Brei-

wick, K. Shelden, and S. Moore. 2003. A review of bowhead whale (Balaena mysticetus) stock identity. J. Cetacean Res. Manag. 5(3):267-279.

Suydam, R. S., and J. C. George. 1992. Recent sightings of harbour porpoises, Phocoena phocoena, near Point Barrow, Alaska. Can Field-Nat. 106:489-492.

Würsig, B., and C. Clark. 1993. Behaviour. In J. J. Burns, J. J. Montague, and C. J. Cowles (Editors), The bowhead whale. Spec. Publ. 2., Soc. Mar. Mammal., Lawrence, Kan., 787 p. 